\title{
Королевство кривых зеркал: эволюция рынков нерегистрируемого алкоголя в России в 1980-2010-е годы
}

\author{
В.В. РАДАЕВ*
}

\begin{abstract}
*Вадим Валерьевич Радаев - доктор экономических наук, профессор, руководитель, Лаборатория экономико-социологических исследований, Национальный исследовательский университет «Высшая школа экономики»; первый проректор, Национальный исследовательский университет «Высшая школа экономики». Адрес: 101000, Москва, ул. Мясницкая, д. 20. E-mail: radaev@hse.ru
\end{abstract}

Цитирование: Радаев В.В. (2018) Королевство кривых зеркал: эволюция рынков нерегистрируемого алкоголя в России в 1980-2010-е годы // Мир России. Т. 27. № 3. C. 28-60. DOI: $10.17323 / 1811-038 X-2018-27-3-28-60$

В работе анализируется эволюичя разнородных рынков нерегистрируемого алкоголя в России с периода позднего социализма до наших дней. Особое внимание уделяется рынку домашнего алкоголя, рынку поддельной и фальсифищированной алкогольной продукцции и рынку неучтенного алкоголя промышленного производства. Нелегальность этих рынков имеет разную подоснову, включая несоблюдение запретов на реализацию определенной продукиии, нарушение прав на использование объектов интеллектуальной собственности или уклонение от уплаты налогов. На основе статистических, опросных и экспертных данных описываются разнородные рынки нерегистрируемого алкоголя и показывается, как меняется их комбинация по мере прохождения через четыре исторических этапа. Они включают (1) этап позднего сочиализма и жесткой антиалкогольной кампании (1980-1991 г2.), (2) этап либеральных реформ и резкого экономического спада (1992-1999 г2.), (3) этап консолидаџии государства и экономического роста (2000-2007 г2.), (4) этап экономической рецессии и новой алкогольной политики (с 2008 г. до настоящего времени). На каждом этапе на фоне меняющихся сложных констелляций политических, законодательных и экономических условий один из рынков активно разви-

\footnotetext{
1 Данная статья является расширенным и доработанным вариантом предшествующей работы [Radaev 2017]. Работа осуществлена при поддержке Программы фундаментальных исследований Национального исследовательского университета «Высшая школа экономики». Мы благодарны З.В. Котельниковой, И.Г. Кратко и Я.М. Рощиной за участие в проекте, Й. Беккерту и М. Дьюи, другим участникам конференции «Интерфейсы между легальностью и нелегальностью на рынках» (5-6 февраля 2014 г.) Института социальных наук Макса Планка (Кельн, Германия) за ценные замечания при обсуждении рукописи.
} 
вался, в то время как другие оставались в неразвитом состоянии или отходили на второй план. Сначала доминировало потребление домашнего алкоголя (самогона); затем произошел всплеск контрафактного и фальсифицированного алкоголя; наконец, наблюдается экспансия рынка неучтенного алкоголя промышленного производства..

Полученные данные свидетельствуют о том, что рынки нерегистрируемого алкоголя имеют тенденцию к расширению во времена экзогенных политических и экономических шоков. В периоды же относительной экономической стабильности и роста они сокращуаются или, по крайней мере, остаются на прежнем уровне. В некоторые периоды рынки регистрируемого и нерегистрируемого алкоголя движутся в противоположных направлениях, в то время как в другие, более короткие, периоды они развиваются параллельно. Изменения в структуре рынков нерегистрируемого алкоголя сопровождаются периодическими переквалификациями продуктов, организаций и транзакций, когда оспариваются $и$ смешаются границы между легальным и нелегальным. При этом отдельные нелегальные виды деятельности сохраняют в той или иной степени свою легитимность в силу двух дополняющих друг друга причин: неосведомленности или толерантности конечных потребителей и представителей госорганов, призванных осуществлять правоприменение. Границы между легитимным и нелегитимным, как правило, более неопределенные и меняются гораздо медленнее.

Ключевые слова: экономическая социология, потребительские рынки, нелегальные рынки, потребление алкоголя, легальность и легитимность, Россия

Социология рынков постепенно заняла ключевые позиции в современной экономической социологии [Fourcade 2007; Fligstein, Dauter 2007; Paдаев 2007]. Разнообразие изучаемых рынков способно поразить воображение. В то же время существует особый тип рынков, который не получил пристального внимания экономсоциологов, особенно за пределами стран бывшего социалистического лагеря: речь идет о незаконном производстве и распространении продукции. Причина этого заключается в отсутствии официальной статистики и других сколь-либо систематизированных данных, а также ограниченных возможностей для прямого этнографического исследования подобных рынков: наблюдается лишь их поверхность, связанная с розничной торговлей, в то время как все предшествующие звенья цепи поставок, как правило, остаются вне поля зрения. Но дело не только в очевидном дефиците эмпирических свидетельств, но и в недостаточной концептуализации данного объекта, проявляющейся в дефиците объясняющих схем.

Мы считаем, что социологи (наряду с представителями других социальных дисциплин) должны более активно заняться изучением подобных рынков, присутствующих во всех без исключения экономиках [Beckert, Wehinger 2011]. Для России, где незаконный оборот продукции в разных формах традиционно занимает важное место, эта тема играет особую роль. Дополнительную значимость в текущий период ей придает отмеченное многими экспертами расширение с 2012-2013 гг. незаконного оборота продукции в самых разных потребительских рынках, когда началась рецессия, вскоре переросшая в экономический кризис.

Нелегальные рынки весьма неоднородны и развиваются разными способами. И мы хотели бы посвятить данную работу анализу структуры и эволюции таких рынков в России с периода позднего социализма до наших дней на примере рынков нерегистрируемого алкоголя. В настоящей статье предпринята попытка решить 
несколько задач. Во-первых, мы представим общую структуру рынков нерегистрируемого алкоголя, демонстрируя их гетерогенность и необходимость рассмотрения их сложных комбинаций. Более подробно мы остановимся на трех разновидностях таких рынков: рынке домашнего алкоголя, рынке контрафактных алкогольных напитков и рынке неучтенного алкоголя промышленного производства.

Во-вторых, мы сконцентрируем внимание на динамических аспектах нелегальных рынков, которые гибко приспосабливаются к меняющейся экономической и политической среде. Исторический аспект анализа является главным для данной работы. Мы используем многообразные статистические, опросные и экспертные данные, собранные по крупицам из разных источников, для демонстрации того, как комбинация разнородных нелегальных рынков проходит через разные стадии своего развития на фоне меняющихся сложных констелляций политических, законодательных и экономических условий. Всего будет выделено четыре этапа. И на каждом этапе мы увидим, что один из изучаемых рынков выходит на передний план, в то время как другие остаются в неразвитом состоянии или обнаруживают нисходящие тренды.

B-третьих, нам важно понять, какие факторы воздействуют на структуру и динамику исследуемых рынков и, в частности, что происходит с ними во времена экзогенных политических или экономических шоков и, наоборот, в периоды относительной политической стабильности и экономического роста.

B-четвертых, мы попытаемся показать, что изменения в структуре нелегальных рынков подпитываются периодической переквалификацией продуктов, организаций и транзакций, которые беспрестанно ставят под сомнение ранее сложившиеся границы между легальным и нелегальным. Мы обратим внимание на то, что некоторые виды нелегальной деятельности сохраняют (или даже завоевывают) свою легитимность благодаря неосведомленности (недостатку знаний и понимания) или толерантности (снисходительному отношению) конечных потребителей продукции и организаций, призванных осуществлять правоприменение. Мы увидим, что границы между легитимным и нелегитимным оказываются еще более размытыми, чем границы между легальным и нелегальным.

\section{Уточнение понятий и классификация рынков нерегистрируемого алкоголя}

Прежде всего, следует уточнить исходные понятия, обратив внимание на нетождественность категорий нелегальной и нерегистрируемой (неучтенной) экономики [Feige 1990; Portes 2010; Radaev 2005; Барсукова 2004]. Продукция может быть легальной, но оставаться нерегистрируемой в силу того, что она не учитывается статистическими и налоговыми органами: хорошим примером здесь выступает производство домашнего алкоголя для собственного потребления как часть неформальной экономики домохозяйств. Легальная продукция может оказаться нерегистрируемой и на формальных рынках - например, в случае спиртосодержащих препаратов, которые потребляются в качестве алкогольных напитков, хотя и не предназначены для этого, и посему не учитываются в продажах алкогольной продукции. В настоящей статье мы будем использовать более широкий термин 
«рынки нерегистрируемого алкоголя», представляющийся более адекватным поставленным задачам.

Классификация рынков нерегистрируемой продукции также заслуживает особого внимания. Чаще всего в специальной литературе выделяют четыре рынка нерегистрируемого алкоголя: (1) нелегально произведенный или контрабандный алкоголь; (2) алкоголь, ввезенный в страну физическими лицами в процессе трансграничной торговли; (3) суррогатный алкоголь, включающий спиртосодержащие жидкости, не предназначенные для потребления; (4) домашний алкоголь [Rehm, Kanteres, Lachenmeier 2010; Lachenmeier, Taylor, Rehm 2011]. В данной работе мы уточним указанную классификацию, выделив пять видов рынков нерегистрируемого алкоголя, составляющие в целом от 25 до 40\% общего потребления алкоголя в России [WHO 2014; оценки автора]. К ним относятся:

- рынок домашнего алкоголя;

- рынок поддельной и фальсифицированной алкогольной продукции;

- рынок неучтенного алкоголя промышленного производства;

- индивидуальная трансграничная торговля алкоголем;

- рынок суррогатного алкоголя.

Эти рынки не часто становятся объектами специальных исследований, в особенности если речь идет о посткоммунистических странах [Lachenmeier, Taylor, Rehm 2011]. Мы сфокусируемся на первых трех, а два последних оставим за рамками нашего исследования.

Домашний алкоголь производится незарегистрированными акторами (домашними хозяйствами), использующими примитивные технологии дистилляции или брожения [Замграев 2002; Rehm, Kanteres, Lachenmeier 2010]. Простейшие самогонные аппараты можно свободно и совершенно легально приобрести на российском рынке по цене менее 100 долл. США; в продаже также распространены наборы для изготовления вина. В отличие от организаций, которые также используют подобные технологии, домашнее производство не отделено от домашнего хозяйства. При этом одна часть домашнего алкоголя изготовляется для нужд собственного потребления в самом домохозяйстве, другая часть продается на нелегальном рынке, преимущественно через неформальные локальные сети. Помимо этого, домашний алкоголь широко используется в качестве средства бартерного обмена, особенно в отдаленной сельской местности, где населением ощущается хронический дефицит денежных доходов [Замграев 2002; Rogers 2005].

Особый случай нелегальных рынков представлен рынками контрафактной продукиии. В настоящее время в российских СМИ контрафактом нередко называют любую продукцию, выпущенную в оборот с какими-либо нарушениями закона. Мы же будем понимать контрафакт в более узком и точном терминологическом смысле - как производство и распространение продукции с незаконным использованием товарных знаков или использованием средств индивидуализации, сходных до степени смешения с оригинальными товарными знаками, с целью сознательного введения в заблуждение потребителей продукции [Радаев, Барсукова, Котельникова 2008; Rutter, Bryce 2008; Kotelnikova 2011; Kotelnikova 2017 ]. По сути, речь идет о подделках и товарах-имитациях, которые относительно редко изготовляются в пределах домашних хозяйств, и их основная часть поставляется организациями (легальными или нелегальными). Производство подделок может 
быть кустарным (подвальным) или промышленным. Добавим, что алкоголь, выпущенный с незаконным использованием товарного знака, чаще всего оказывается нерегистрируемым, хотя в принципе он может продаваться официально, прячась под видом оригинального продукта.

Неучтенный алкоголь промышленного производства имеет различное происхождение: такие алкогольные напитки могут незаконно производиться как легальными (зарегистрированными), так и нелегальными организациями; легально и нелегально произведенный алкоголь может ввозиться контрабандными способами и/или незаконно продаваться через торговые объекты и рестораны, у которых отсутствуют соответствующие лицензии. Все эти виды деятельности при их различии объединяет один общий признак: они совершаются в разных звеньях цепи поставок с целью уклонения от уплаты налогов и прочих обязательных платежей.

В данной работе мы исключим из рассмотрения индивидуальную трансграничную торговлю алкоголем. Хотя подобный тип импортного алкоголя не учитывается в стране, где происходит его конечное потребление, сами по себе транзакции и перевозки, осуществляемые международными пассажирами, совершенно законны, если при этом не нарушаются установленные квоты на ввоз алкогольных продуктов. Но подобная трансграничная торговля играет значительную роль лишь в сравнительно небольшом количестве стран, большей частью входящих в состав Европейского союза [Rehm, Kailasapillai, Larsen, Rehm, Samokhvalov, Shield, Roerecke, Lachenmeier 2014, p. 884], в то время как в России объемы перемещаемого через границы алкоголя физическими лицами в целом некритичны. Правда, практикуется форма контрабанды алкоголя, которая совершается под видом ввоза физическими лицами якобы для собственного потребления (см. ниже).

Еще один рынок нерегистрируемого алкоголя, который не попадает в рамки представленного исследования, связан с суррогатныл алкоголем - спиртосодержащих жидкостей, которые зачастую производятся и реализуются совершенно легально, но при этом не предназначены для потребления [Gil, Polikina, Koroleva, McKee, Tomkins, Leon 2009]. Они включают три вида продуктов: медицинские препараты, косметические препараты (одеколоны, лосьоны) и предметы бытовой химии (например, незамерзающие стеклоомывающие жидкости). Этот рынок важен для России (в первую очередь это касается периода 1990-х гг.) и заслуживает особого внимания, поскольку потребление суррогатных напитков способно нанести серьезный вред здоровью и представляет опасность для жизни, особенно в тех случаях, когда их изготовление сопровождается фальсификацией продуктов и добавлением запрещенных токсичных веществ ${ }^{2}$. Однако в этом случае проблема заключается в отсутствии сколь-либо надежных систематических данных, которое не позволяет нам анализировать должным образом этот вид рынка нерегистрируемого алкоголя.

2 Так, в декабре 2016 г. в Иркутске произошло массовое отравление суррогатным алкоголем; пострадали 122 чел., 74 чел. скончались. Пострадавшие употребляли парфюмерное косметическое средство «Концентрат для ванн “Боярышник”», содержащий метанол, использование которого запрещено российским законодательством. 


\section{Концептуальная основа}

Говоря о концептуальных основаниях, прежде всего мы исходим из того, что нелегальные рынки, или рынки нерегистрируемой продукции, принципиально гетерогенны [Beckert, Wehinger 2011]. Их нелегальность может иметь совершенно разную подоснову, включая, например, нарушение запрета на реализацию определенной продукции (продажа домашнего алкоголя), несоблюдение прав на использование объектов интеллектуальной собственности (производство и распространение поддельной продукции и товаров-имитаций) или уклонение от уплаты налогов (неучтенное производство или продажа).

Заметим, что нелегальный характер организаций, продукции и транзакций не связаны между собой жестким и однозначным образом. Организации могут быть легальными (зарегистрированными), но при этом заниматься производством запрещенной продукции или совершать какие-либо незаконные операции, в то время как нелегальные (незарегистрированные) организации могут продвигать на рынок легальные товары. Транзакции могут оказаться незаконными по целому ряду причин: продажи данного вида продукции незаконны (случаи домашнего или контрафактного алкоголя); организация не имеет соответствующей лицензии; организация имеет необходимые лицензии, но не соблюдает установленные условия продаж, нарушая наложенные законом ограничения (например, продает алкоголь лицам, не достигшим 18 лет); или попросту продавец не фиксирует отдельные транзакции, занижая тем самым объем фактически реализованного товара. Продукция, в свою очередь, может быть легальной, нелегальной (контрафактной и/или фальсифицированной по своему составу и свойствам) либо легальной, но используемой не по назначению, как в случае суррогатного алкоголя, не предназначенного для потребления в качестве пищевого продукта.

Нелегальные рынки также способны порождать разнородные эффекты: например, качество домашнего алкоголя может быть не хуже или даже лучше легального алкоголя промышленного производства, что не раз доказывалось исследованиями его химического состава [Rehm, Kailasapillai, Larsen, Rehm, Samokhvalov, Shield, Roerecke, Lachenmeier 2014], в то время как коммерческий домашний алкоголь, предназначенный для продажи на нелегальном рынке и нацеленный на более выраженную интоксикацию организма, может приводить к более пагубным последствиям для здоровья, не говоря уже об ущербе для общественных интересов, вызванном уходом от уплаты налогов [Немцзов 2009]. Распространение контрафактной (поддельной) продукции способно порождать риски не только для здоровья отдельных потребителей, но и наносить ущерб корпоративным интересам правообладателей путем нарушения их прав на объекты интеллектуальной собственности, подрыва стимулов к инвестициям и осуществлению инновационных разработок [Радаев, Барсукова, Котельникова 2008; Kotelnikova 2011]. В свою очередь, неучтенное производство оригинального алкоголя (например, изготовление неучтенной продукции в третью-четвертую смены) подрывает интересы государства, недополучающего налоги, и тем самым наносит вред общественным интересам и обеспечению общего благосостояния. Помимо этого, нелегальная деятельность почти неизбежно сопряжена с недобросовестной конкуренцией, приводящей к потере части продаж законопослушными участниками рынка [Radaev 2005]. 
Какие из этого следуют выводы? Во-первых, необходимы спецификация и декомпозиция совокупности нелегальных рынков, изучение их сложной структуры. Во-вторых, разделив нелегальные рынки, мы должны по возможности всесторонне анализировать их разнообразные комбинации и прослеживать, как эти взаимосвязанные рынки развиваются с течением времени. Поэтому в данной работе мы сфокусируемся на динамических аспектах развития рынков нерегистрируемого алкоголя.

Делая акцент на историческом подходе, мы обратим внимание на сложные сочетания экономических, политических и правовых факторов, которые оказывали влияние на развитие рынков алкогольной продукции. Особенно интересен вопрос о том, как ведут себя рынки нерегистрируемого алкоголя в периоды экзогенных политических и экономических шоков, таких как антиалкогольные кампании или экономические кризисы, и, наоборот, в периоды политической стабильности и экономического роста. Предшествующие исследования по России и другим странам показывали разные результаты в отношении влияния экономических шоков на потребление алкоголя [Jukkala, Makinen, Ferlander, Vagero, Kaslitsyna 2008; de Goeij, Suhrcke, Toffolutti, van de Mheen, Schoenmakers, Kunst 2015]².

Существует обширный корпус специальной литературы, демонстрирующей, что повышение цен на легальный алкоголь, как правило, отрицательно связано с уровнем его потребления [Wagenaar, Salois, Komro 2009], хотя в части интенсивного потребления этот эффект может быть ограничен [Byrne, Shakeshaft, Petrie, Doran 2013]. При этом характер воздействия роста розничных цен на нерегистрируемый алкоголь не столь очевиден, однако многие эксперты убеждены, что в результате повышения цен на легальный алкоголь потребление нерегистрируемого алкоголя (при условии его доступности) должно увеличиваться [Haworth, Simpson 2004]. Тем самым более дешевый нерегистрируемый алкоголь, по крайней мере, отчасти замещает снижающееся потребление более дорогого легального алкоголя [Andrienko, Nemtzov 2005].

Ограничительные меры со стороны государственных регуляторов, снижающие экономическую и физическую доступность легального алкоголя, действительно могут результироваться в снижении его продаж и тем самым стимулировать использование разных видов нерегистрируемого алкоголя. Хотя подобная зависимость отнюдь не безусловная: опыт скандинавских стран со сходным северным стилем потребления алкоголя показывает, что ограничения, вводимые в рамках алкогольной политики государства, вовсе необязательно приводят к росту нелегального алкоголя, многое зависит от конкретных обстоятельств в той или иной стране [Lindström 2005].

Масштабы рынков нерегистрируемого алкоголя, несомненно, чувствительны к жесткости санкций против нарушителей закона, но они еще более чувствительны к эффективности практик правоприменения против недобросовестных дилеров со стороны государства.

Изменения в стилях потребления и предпочтениях тех или иных алкогольных напитков могут порождаться и серьезными сдвигами в культурных восприятиях населения: например, в России в 2000-е гг. представители более молодых возрастных групп перешли от потребления водки и ликероводочных изделий к потреблению пива, а более образованные слои начали отказываться от крепких

3 Хотя чаще исследователи приходили к выводу о снижении потребления легального алкоголя в периоды кризисов. 
алкогольных напитков в пользу вина [Денисова 2010; Roshchina 2013]. Подобные изменения могут развиваться благодаря внутренним правилам, вырабатываемым в сетях длинных прямых и непрямых социальных связей, и формировать повторяющиеся циклы потребления, длящиеся обычно по 10-20 лет [Skog 1986]. Мы осознаем, что культурные факторы оказывают существенное и долгосрочное влияние на уровень и структуру потребления алкоголя, однако их воздействие остается за рамками данного исследования.

Легальные и нелегальные рынки нередко рассматриваются как своего рода «сообщающиеся сосуды»: изменения на легальных рынках неизбежно влияет на то, что происходит на нелегальных, и наоборот [Thamarangsi 2013]. Как правило, эта позиция опирается на представление о том, что в краткосрочных периодах потребление алкоголя населением относительно постоянно, поэтому если растут продажи легального алкоголя, то нелегальный алкоголь отступает. Если же по тем или иным причинам продажи легального алкоголя снижаются, то они быстро замещаются потоками нелегальной продукции. Впрочем, возможна и другая точка зрения, указывающая на то, что связи между легальными и нелегальными рынками более сложны: так, например, нелегальные рынки можно образно представить в виде «кривых зеркал», способных давать как сходные, так и сильно искаженные (до противоположного) отражения легальных рынков [Radaev 2017]. В дальнейшем мы увидим, что на одних этапах определенные нелегальные рынки могут двигаться в противоположных направлениях по сравнению с легальными, в то время как на других этапах эти рынки способны двигаться параллельно, демонстрируя собственные логики. В этом случае связь между легальными и нелегальными рынками оказывается не столь однозначной.

Отдельный сюжет связан с вопросами легитимности нелегальной деятельности. Мы разделяем представление о том, что нелегальность с точки зрения закона вовсе необязательно сопряжена с отсутствием легитимности с точки зрения социальных восприятий [Van Schendel, Abraham 2005], а также поддерживаем позицию, в соответствии с которой потребители нерегистрируемой продукции могут вводиться в заблуждение продавцами или приобретать эту продукцию вполне сознательно, прекрасно понимая ее характер и происхождение [Grossman, Shapiro 1988]. В связи с этим мы выделяем две основные причины сохранения легитимности незаконных видов деятельности. Первая причина заключается в неосведомленности (недостатке знаний и понимания), вторая - в толерантности (снисходительном отношении к нарушениям), которая может быть обусловлена готовностью принять возможные негативные последствия или желанием извлечь для себя какие-либо выгоды (например, от приобретения нерегистрируемой продукции по более низким ценам).

\section{Источники данных}

Исследование разнородных рынков нерегистрируемого алкоголя требует привлечения разнообразных источников данных. Официальная статистика рынков нерегистрируемой продукции по определению отсутствует. Иногда применяются досчеты нелегальной составляющей, но они, как правило, фрагментарны и не всегда ясны с методологической точки зрения. 


\section{Статистические данные}

Поскольку статистические данные, напрямую отражающие уровень и динамику нерегистрируемого алкоголя, за редкими исключениями, отсутствуют, мы вынуждены собирать их из самых разных источников для получения косвенных оценок масштабов неучтенного производства и продаж алкогольных напитков, а также для определения эффективности мер, предпринимаемых правообладателями и правоохранительными органами по защите прав интеллектуальной собственности. Помимо данных Росстата, использовались базы ведомственной статистики, как правило, содержащие данные с середины 2000-х гг.: в их числе данные Росалкогольрегулирования, Роспотребнадзора, Роспатента, Федеральной таможенной службы России.

\section{Данные опросов населения}

Мы также привлекли данные опросов населения для изучения его потребительских предпочтений. Данные получены в ходе Российского Мониторинга социально-экономического положения и здоровья населения НИУ ВШЭ (RLMS-HSE), который представляет собой серию ежегодных общенациональных репрезентативных опросов индивидов и домашних хозяйств, проводимых на базе вероятностной стратифицированной многоступенчатой территориальной выборки. Используемые нами данные 1994-2015 гг. репрезентируют взрослое население России и все типы поселений. Главными параметрами являются потребление основных алкогольных напитков промышленного и домашнего производства в течение 30 дней, предшествовавших опросу, и объем их потребления. Данные по потреблению самогона собирались с 1994 г., а по потреблению и покупкам контрафактного алкоголя - с 2012 г. Для более подробного анализа потребления домашнего и контрафактного алкоголя используются данные 23-й волны RLMS-HSE (2014 г.), в ходе которой было опрошено 14968 взрослых респондентов в возрасте от 15 лет и старше.

Мы вполне осознаем, что конечные потребители, выступающие нашими респондентами, имеют ограниченные возможности различения между легальными и нелегальными продуктами и транзакциями, причем их знания в большей степени зависят от характера нелегального рынка: так, конечные потребители, как правило, не в состоянии отличить нелегально произведенный продукт от легального, если эти продукты идентичны. Они лишь могут догадываться, если столкнутся с заметными различиями в уровне цен или если более дешевый продукт распространяется с какими-либо нарушениями. В отдельных случаях (но явно не во всех) потребители способны идентифицировать поддельные продукты, если они отличаются от оригинала по качеству или вкусовым характеристикам, т.е., как прави-

\footnotetext{
4 Мониторинг проводится НИУ ВШЭ и ЗАО «Демоскоп» при участии Центра народонаселения Университета Северной Каролины в Чапел Хилле и Института социологии РАН // http://www.cpc.unc.edu/projects/rlms; http://www.hse.ru/rlms
} 
ло, уже после потребления этих продуктов. В то же время покупатели без труда идентифицируют продукты домашнего производства, потому что, как правило, их происхождение не скрывается. Таким образом, RLMS-HSE и другие стандартизированные опросы могут представить вполне надежные данные об использовании домашнего алкоголя, которые совершенно отсутствуют в официальной и деловой статистике.

\section{Экспертная статистика}

Для анализа советского и раннего постсоветского периодов, где дефицит данных представляется наиболее острым, нами будет использоваться статистика, предложенная ведущими экспертами по их собственным расчетам. Самым известным примером служат работы В. Тремла [Treml 1982; Treml 1997], который досчитывал объемы потребления самогона на основе динамики сверхнормативного потребления сахара в домашних хозяйствах с 1960-х гг., как это позднее делалось советскими статистическими органами в 1980-е гг. Но в данной работе мы будем непосредственно опираться на статистические расчеты А.В. Немцова, проводимые с начала 1980-х гг. и построенные на другой методологии, но дающие в целом сходные результаты. Эта методология основана на расчетах динамики смертности от внешних причин с алкоголем в крови умерших [Немц̧ов 2009]. Очевидно, что каждая методология имеет серьезные ограничения, но других, более надежных, расчетов в ряде случаев просто не обнаруживается.

Далее мы будем исходить из того, что с начала 1980-х гг. российские рынки прошли в своем развитии четыре основных этапа:

- этап позднего социализма и жесткой антиалкогольной кампании (1980-1991 гг.);

- этап либеральных реформ и резкого экономического спада (1992-1999 гг.);

- этап консолидации государства и экономического роста (2000-2007 гг.);

- этап экономической рецессии и новой алкогольной политики (с 2008 г. до настоящего времени).

\section{Первый и второй этапы эволюции рынков нерегистрируемого алкоголя}

\section{Первый этап (1980-1991 г2.)}

Первый из обозначенных этапов характеризуется относительно длительным экономическим застоем позднего социализма, на фоне которого применялись суровые меры по ограничению доступности алкогольных напитков. Печально известная горбачевская антиалкогольная кампания в 1985-1987 гг. привела к существенному повышению цен на алкогольные напитки, введению многочисленных запретов на производство, продажи и потребление, ужесточению наказаний за нарушения, связанные с использованием алкоголя [White 1996; 
Bhattacharya, Gathmann, Miller 2012]. В результате потребление легального алкоголя быстро сократилось в два с половиной раза. В этот период основным видом нерегистрируемого алкоголя становится самогон в качестве продукта домашней дистилляции, в то время как рынки контрафактной и неучтенной продукции промышленного производства пребывают в неразвитом состоянии - в большей степени благодаря жесткому государственному контролю над деятельностью хозяйственных организаций. В то же время контроль над массой мелких домашних производителей остается неэффективным, ослабляясь высокой толерантностью населения (а отчасти и правоохранительных органов) к практикам самогоноварения. Поэтому как минимум половина падения потребления легального алкоголя в ходе горбачевской реформы была быстро замещена потреблением самогона, которое к 1987 г. достигло почти двух третей (64\%) общего потребления алкоголя [Заиграев 2002; Немиов 2009] (рисунок 1).

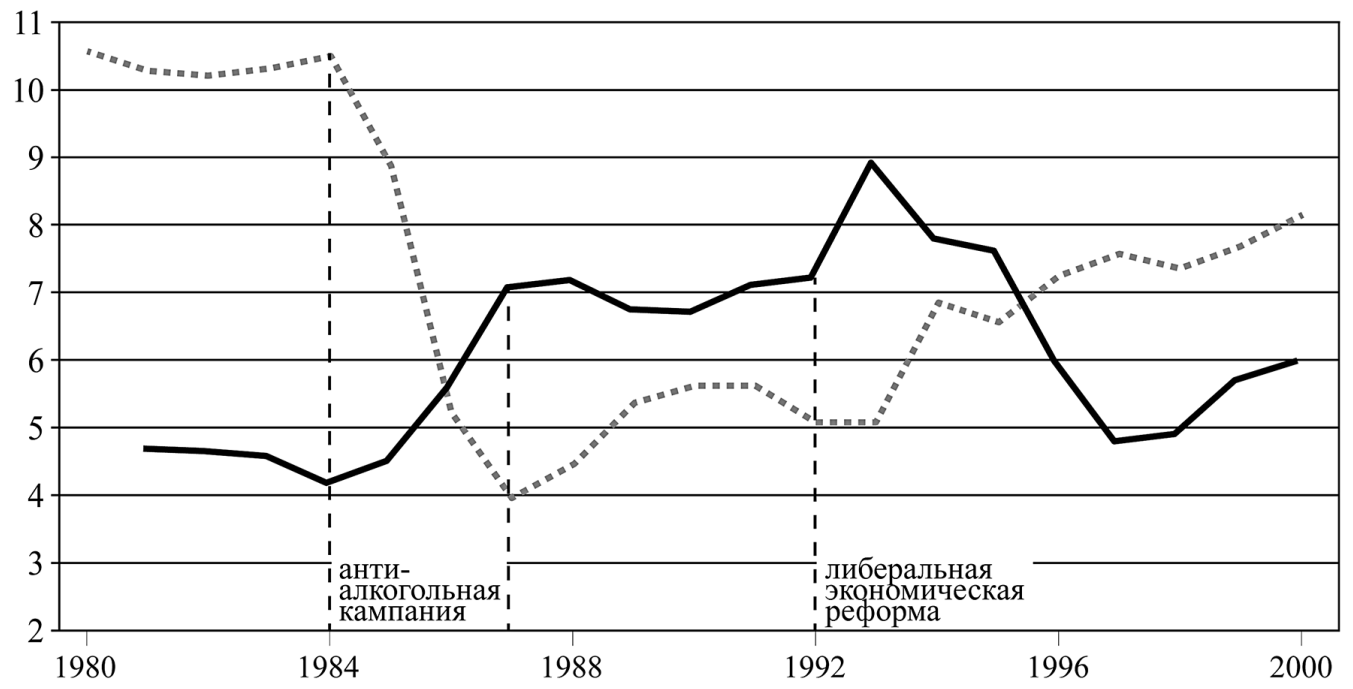

$\infty-\infty$ потребление легального алкоголя (Росстат)

— потребление нелегального алкоголя (А.В. Немцов)

Рисунок 1. Душевое потребление легального и нелегального алкоголя в России в 1980-2000 гг., в литрах чистого алкоголя

Источник: данные Росстата, [Немиов 2009].

После сворачивания горбачевской антиалкогольной кампании в 1988-1991 гг. потребление легального алкоголя частично восстановилось (прежде всего за счет растущего потребления водки), при этом потребление самогона сохранялось на высоком уровне, достигая 54\% общего объема, по крайней мере до начала 1990-х гг. [Немиоов 2009]. 
Второй этап (1992-1999 г2.)

Второй этап начался с разворачивания в 1992 г. либеральных экономических реформ, которые привели к легализации предпринимательской деятельности, либерализации внутренней и внешней торговли, резкому падению объемов производства и ослаблению контроля над рынками со стороны государства, включая ликвидацию государственной монополии на производство алкогольных напитков.

Дерегулирование торговли сопровождалось взлетом потребления алкоголя (легального и нелегального), и к 1994 г. в России был побит исторический рекорд: душевое потребление в пересчете на чистый алкоголь выросло до 18 л. [Немцов 2016]. И хотя потребление самогона в 1990-е гг, по некоторым данным, несколько выросло [Тапилина 2006], резкий рост нелегального алкоголя происходил уже преимущественно за счет других источников. На дерегулированный российский рынок хлынул дешевый фабричный алкоголь, включая чистый спирт, а также напитки низкого качества и откровенные подделки, копирующие известные бренды, многие из которых импортировались в страну или зачастую ввозились контрабандными способами новыми частными предпринимателями [Немцов 2009]. Заметим, что подобный массовый приток импортного алкоголя наблюдался в период реформ и в других восточно-европейских странах [Moskalewicz, Simpura 2000].

В этот период многочисленные зарегистрированные организации или незарегистрированные группы вовлекались в сложные комбинации легальных, полулегальных и нелегальных операций. Значительная часть нелегально произведенного или ввезенного в страну контрабандного алкоголя не попадала в официальную статистику. Дешевый и низкокачественный алкоголь импортировался в страну с использованием так называемых «серых схем», позволявших уклоняться от уплаты таможенных платежей и НДС [Radaev 2005].

Анализируя второй этап развития, очень трудно найти надежные систематические данные о масштабах рынков нерегистрируемого алкоголя, но, по общим оценкам, производство и распространение контрафактного алкоголя в этот период процветали. По данным Роспотребнадзора, проводящего регулярные проверки качества продукции, в середине 1990-х гг. 30-40\% проверенных алкогольных напитков оказывались ненадлежащего качества или даже представляющими опасность для здоровья, причем это было особенно характерно для импортируемого алкоголя. Заметим, что преобладающая часть контрафактного алкоголя нелегально производилась или ввозилась контрабандно в Россию, в том числе для легальной продажи на внутреннем рынке. Важным косвенным свидетельством остроты данной проблемы и широкого распространения нелегальной алкогольной продукции в этот период служит резкий взлет смертности, сопряженной с чрезмерным потреблением алкоголя или отравлениями некачественным алкоголем [Treisman 2008; Leon, Shkolnikov, McKee 2009].

Несмотря на принятие в 1992 г. специального Федерального закона «О товарных знаках, знаках обслуживания и наименованиях мест происхождения товаров», законодательство, защищавшее права интеллектуальной собственности и, в частности, зарегистрированные товарные знаки, оставалось относительно неразвитым. Но что более важно, крайне неэффективными оказались схемы правоприменения, были не наработаны соответствующие судебные практики, судьи еще плохо 
разбирались в вопросах интеллектуальной собственности и зачастую не понимали, почему ее нужно конфисковывать и тем более уничтожать.

Второй этап завершился финансовым кризисом 1998 г., когда в результате девальвации российский рубль потерял три четверти своей стоимости. В этих условиях на определенное время импорт алкогольных напитков стал менее эффективным, выросло отечественное производство, и в течение нескольких лет наблюдалась очередная волна возрождения самогоноварения [Заиграев 2002; Немиов 2009].

\section{Третий и четвертый этапы эволюции рынков нерегистрируемого алкоголя}

Третий этап (2000-2007 г2.)

Данный этап (единственно благополучный из всех) был отмечен устойчивым экономическим ростом, когда среднегодовой рост ВВП и реальных располагаемых доходов населения составлял 7 и $10 \%$ соответственно. Экономический рост сопровождался не только ростом материального благосостояния потребителей, но и снижением относительных цен на легальные алкогольные напитки. Для иллюстрации приведем пример: число обычных пол-литровых бутылок водки, которые можно было купить за одну среднемесячную зарплату, в 1998-2011 гг. выросло в 3,7 раза (с 51 до 189 бутылок). Добавим, что усиливающийся на всех фронтах государственный контроль способствовал сокращению масштабов потребления нерегистрируемого алкоголя (см. ниже).

Четвертый этап (2008-2018 г2.)

Четвертый этап начался с кризиса 2008-2009 гг., за которым последовали рецессия 2012-2013 гг. и новый экономический кризис 2014-2016 гг. В период рецессии среднегодовой прирост ВВП упал до $1 \%$, а прирост реальных располагаемых доходов населения - до 3\%; а в период нового кризиса оба показателя перешли в минусовую зону.

В этот же период с созданием в 2009 г. Росалкогольрегулирования (специального государственного органа по регулированию алкогольного рынка) развернулась активная фаза антиалкогольной реформы. Были введены разнообразные ограничительные меры, касающиеся производства, реализации и потребления алкогольных напитков. В 2011 г. появились новые технические требования к производителям алкоголя, нацеленные на вытеснение мелких игроков. Одновременно производилось перелицензирование производителей и дистрибьюторов алкогольных напитков, приведшее к сокращению их общего числа на 30-40\%. С 2012 г. стали ограничивать продажу алкогольной продукции в вечернее и ночное время, а места размещения торговых объектов, торгующих алкоголем, должны были находиться на определенной дистанции от образовательных, медицинских, спортивных и культурных 
учреждений. В этом же году началось ступенчатое сокращение рекламы алкогольных напитков на телевидении, радио, в печатных СМИ, которое завершилось ее запрещением, а с 2013 г. был наложен запрет на продажу пива в киосках.

Одной из наиболее заметных мер явилась введенная с 2012 г. ускоренная индексация ставок акцизов на алкогольную продукцию, сопровождаемая повышением минимальных розничных цен на водку (МРЦ). В результате всего за четыре года (2011-2014 гг.) ставки акцизов на водку были повышены в 2,4 раза, на отечественное вино в 2 раза, на отечественное пиво в 2,3 раза. За эти годы МРЦ на пол-литровую бутылку водки была увеличена с 89 до 220 руб., т.е. также в 2,5 раза. Чтобы показать ощутимость данного роста, отметим, что реальные располагаемые денежные доходы населения выросли в 2011-2014 гг. лишь на 7\%. Объективно эти меры могли создать дополнительные стимулы для производства и распространения нерегистрируемого алкоголя и деятельности, нацеленной на уход от уплаты налогов.

\section{Усиление борьбы с контрафактной продукцией}

В конце 2000-х гг. произошло явное ужесточение ответственности за нарушения в сфере интеллектуальной собственности: во всех основных кодексах (Уголовном, Гражданском, Административном) были усилены меры наказания за незаконное использование торгового знака [Радаев, Барсукова, Котельникова, Куракин 2010]. Появилась также возможность ликвидировать юридическое лицо или приостановить деятельность индивидуального предпринимателя, конфисковать у нарушителя оборудование, прочие устройства и материалы, использованные или предназначенные для совершения нарушения. В конце 2014 г. пороги крупного ущерба применительно к контрафактным табачным изделиям или алкогольной продукции были понижены до 100 тыс. руб., стимулируя правоохранительные органы к более активной деятельности.

Что более важно, в ходе третьего этапа наблюдались существенные позитивные сдвиги в практиках правоприменения [Радаев, Барсукова, Котельникова 2008]: значительно активизировалась Федеральная таможенная служба; число административных дел, возбужденных против компаний-нарушителей по инициативе ФТС России, за короткий период 2004-2006 гг. выросло в 10 раз. Начиная с 2007 г. таможенные органы задерживали более чем по 10 млн единиц контрафактного товара ежегодно, а в отдельные годы (2012, 2015-2016 гг.) это число удвоилось. При этом в числе наиболее частых предметов правонарушений фиксировались алкогольная продукция и укупорочные изделия (пробки от водочных бутылок).

Решительно изменились судебные практики. Число дел о незаконном использовании товарных знаков, рассмотренных арбитражными судами в 2004-2009 гг, увеличилось более чем в десять раз, а в 2010-2015 гг. оно стабилизировалось на достигнутом высоком уровне [Радаев, Бердыиева, Конрой, Котельникова 2017], все чаще решения принимались в пользу компаний-правообладателей торговых марок. Число недобросовестных участников рынка, привлеченных к уголовной ответственности за незаконное использование товарных знаков, за 2004-2010 гг. выросло в 18 раз.

Компании-правообладатели торговых марок также стали в большей степени заботиться о защите своих прав на интеллектуальную собственность. В частности, 
число заявок на государственную регистрацию и защиту товарных знаков в Роспатенте в 2004-2012 гг. выросло более чем в 1,5 раза, а затем относительно стабилизировалось на максимальном достигнутом уровне. Число товарных знаков, поданных на государственную регистрацию в Таможенный реестр объектов интеллектуальной собственности (ТРОИС), увеличилось в 2004-2016 гг. более чем в 10 раз. Добавим, что алкогольная продукция в ТРОИС занимает 13\%, это одна из трех самых крупных товарных групп [Радаев, Бердышева, Конрой, Котельникова 2017].

\section{Снижение потребления недоброкачественного алкоголя}

Неплохим показателем улучшения ситуации может послужить динамика доли алкогольных напитков ненадлежащего качества или представляющих опасность для потребителей по данным проверок Роспотребнадзора в организациях торговли.

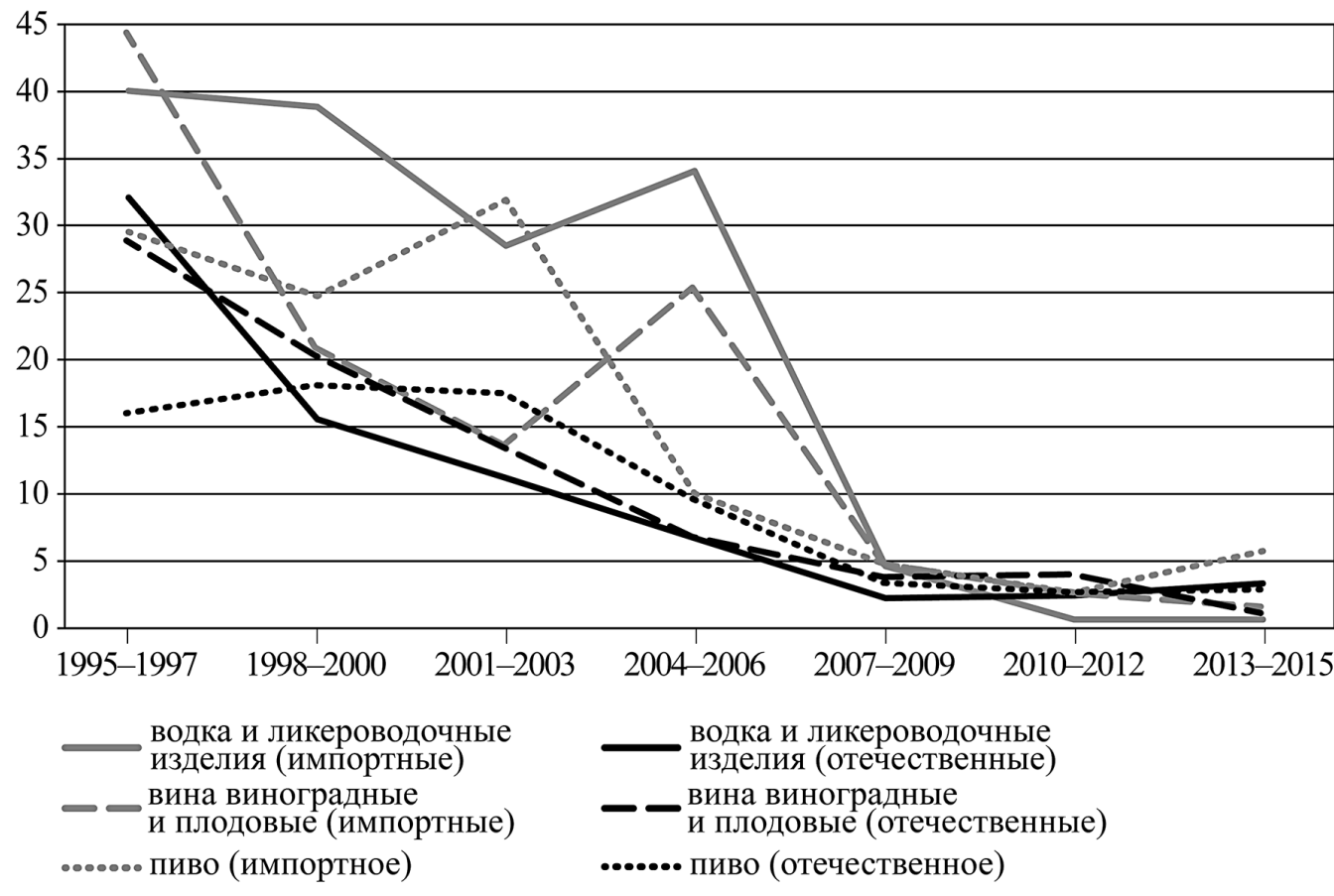

Рисунок 2. Доля алкогольных напитков ненадлежащего качества или представляющих опасность для потребителей в 1995-2015 гг., \% от количества отобранных образцов (проб) товаров по каждой товарной группе ${ }^{1}$

Источник: данные Росстата, данные проверок Роспотребнадзора в организациях торговли.

1 Мы выделили семь трехгодовых интервалов, чтобы устранить годовые флуктуации и сделать тренды более различимыми. 
В середине 1990-х гг., когда начали собираться эти данные, доля подобных недоброкачественных алкогольных напитков, среди которых могла скрываться контрафактная продукция, находилась на весьма высоком уровне, достигая в среднем по основной части алкогольных напитков 30-40\% (рисунок 2). Затем, с начала 2000-х гг., масштабы выявленных алкогольных напитков ненадлежащего качества или представляющих опасность для потребителей начали уверенно снижаться. В середине 2000-х гг. качество импортной водки и импортного вина стало, судя по данным проверок, лучше, а доля недоброкачественного отечественного алкоголя (водки и вина) снижалась в течение всего периода наблюдения и в итоге упала ниже 5\%. В 2013-2015 гг. эта доля уже не уменьшалась, а по отдельным позициям (импортное пиво) выросла, но все же по сравнению с 1990-ми гг. доля недоброкачественной продукции остается на минимальном уровне.

\section{Потребление контрафактного алкоголя по данным опросов населения}

Чтобы дополнить данные ведомственной статистики, посмотрим на результаты опроса RLMS-HSE 2014 г., касающиеся контрафактного алкоголя. Выясняется, что 6\% тех, кто потреблял алкогольные напитки в течение последних 30 дней, по их мнению, потребляли и алкоголь с поддельными товарными знаками. Также 6\% покупателей алкоголя в течение последних 30 дней сообщили, что покупали алкогольные напитки, которые были ими идентифицированы как контрафактные (поддельные) в процессе покупки или после ее завершения. Следует оговориться, что, в отличие от домашнего алкоголя, который идентифицируется относительно легко, в данном случае мы должны относиться к полученным данным с определенной осторожностью, понимая ограниченные возможности покупателей отличить контрафактный алкоголь от оригинального. Впрочем, это может означать и то, что часть контрафактного алкоголя не распознается потребителями, и цифры реального потребления контрафакта могут оказаться выше.

Опросные данные о приобретении контрафактной алкогольной продукции до 2012 г. отсутствуют. Но из серии проведенных нами углубленных интервью в период с 2003 г. мы знаем, что ситуация с пресечением контрафакта в течение третьего этапа улучшилась благодаря серьезным изменениям в государственной политике в отношении распространителей контрафактной продукции [Радаев, Барсукова, Котельникова 2008; Радаев, Барсукова, Котельникова, Куракин 2010].

\section{Взлет и падение самогона}

Возникает вопрос, не произошло ли очередное замещение алкоголя промышленного производства домашним алкоголем, как это случилось, например, в середине

\footnotetext{
5 Данная часть проекта в 2012-2013 гг. была поддержана академическим грантом Международного альянса за ответственное потребление алкоголя (The International Alliance for Responsible Drinking, IARD).
} 
1980-х гг. В данном разделе мы вновь обратимся к опросным данным RLMS-HSE и покажем, что к 2000-м гг. ситуация коренным образом изменилась. Мы обнаруживаем, что доля потребителей водки и других легальных крепких спиртных напитков в течение последних 30 дней снижалась в 1995-2007 гг., стабилизировалась в 2008-2011 гг. и вновь пошла на убыль с 2012 г. Доля потребителей пива повышалась в 1996-2000 гг., стабилизировалась в 2001-2005 гг. на исторически максимальном уровне и несколько снизилась после 2006 г. Доля потребителей вина после некоторого снижения в 1995-2000 гг. испытала повышающий тренд в 2001-2008 гг. с последующей стабилизацией [Радаев, Котельникова 2016].

Что же касается самогона, то доля его потребителей в 1996-2000 гг. двигалась в противоположном направлении по отношению к доле потребителей водки и ликероводочных изделий, замещая отчасти сокращающееся потребление фабричной водки. Но затем, с 2001 г., на фоне растущих реальных доходов и экономической доступности легального алкоголя началось постепенное снижение доли потребителей самогона с 19 до 5\% пьющего населения (рисунок 3). Этот тренд обозначил новое явление, характерное для третьего этапа: доли потребителей крепкого алкоголя промышленного и домашнего производства в этот период снижались параллельно, и говорить об их взаимном замещении не приходится. Примечательно и то, что в ходе четвертого этапа, начиная с 2010 г., этот тренд прервался, но потребление самогона стабилизировалось на уровне исторического минимума - 5-6\% потребителей алкоголя [Radaev 2016].

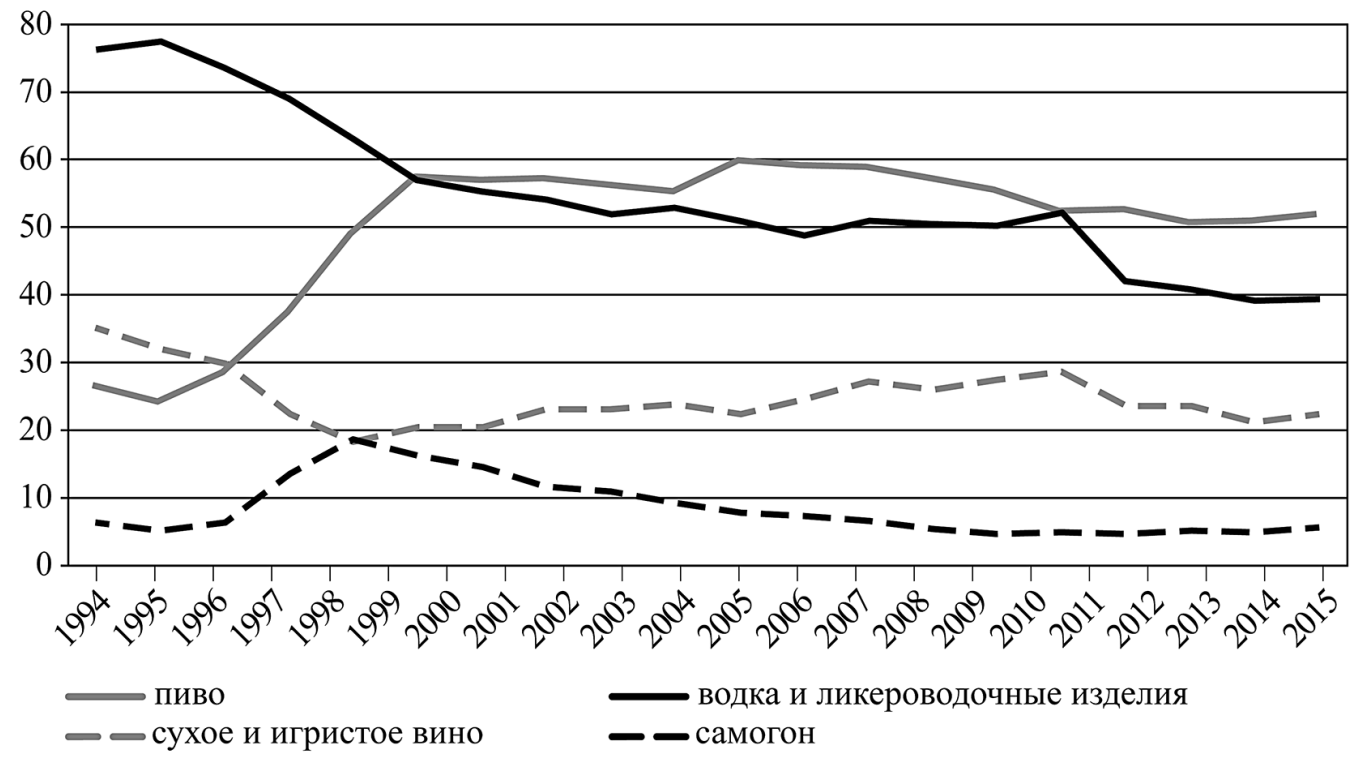

Рисунок 3. Доли потребителей водки, вина, пива и самогона в течение последних 30 дней в 1994-2015 гг., \%

Источник: RLMS-HSE. 
Рассмотрим потребление домашнего алкоголя чуть более подробно. Данные 23-й волны RLMS-HSE (2014 г.) показывают, что 10,5\% респондентов, потреблявших алкогольные напитки в течение последних 30 дней, пили домашний алкоголь, который составил 9,6\% общего потребления в пересчете на чистый алкоголь, а в объеме потребляемого домашнего алкоголя самогон по-прежнему преобладал, составляя $83,7 \%$.

Мы столкнулись с тем, что производители домашнего алкоголя отказывались сообщать в ходе опроса о том, что они продавали домашний алкоголь на рынке, поскольку это запрещено законом, но при этом респонденты готовы были отвечать на вопросы о покупках домашнего алкоголя, и здесь у них не возникали затруднения с определением происхождения приобретаемого алкоголя. Нам удалось выяснить, что 6\% тех, кто покупал алкогольные напитки в течение последних 30 дней (для себя или для других людей), приобретал домашний алкоголь на нелегальном рынке, и в $90 \%$ случаев речь шла о покупке самогона. Эти данные указывают на то, что нелегальный рынок коммерческого домашнего алкоголя по-прежнему существует, хотя размеры его уже невелики.

\section{Неучтенные производство и продажа алкогольных напитков}

Снижение объемов производства и продаж контрафактного и домашнего алкоголя сопровождается на четвертом этапе развития некоторой экспансией третьего типа рынков нерегистрируемого алкоголя, связанного с неучтенным производством и продажей оригинальных алкогольных напитков промышленного производства в целях уклонения от уплаты налогов. Этот тип нелегальной деятельности зачастую практикуется легальными (зарегистрированными) предприятиями, например, производящими водку из неучтенного спирта во время ночных смен на том же самом заводском оборудовании. Именно этот тип рынков нерегистрируемого алкоголя (несомненно существовавший и ранее) и приобрел особую важность в 2010-е гг. Тогда (да и в настоящее время) использовались фальшивые акцизные марки, продажи часто осуществлялись через торговые объекты, не имеющие соответствующих лицензий, или же алкоголя реализовывалось больше, чем демонстрировалось в статистической и налоговой отчетности.

Найти какие-либо систематичные и достоверные данные по неучтенному алкоголю крайне трудно. Чаще всего пытаются применить тот или иной балансовый метод, рассчитывая разницу, например, между объемами производства алкогольной продукции и объемами ее продаж (с учетом экспортного-импортного сальдо), но и в этом случае могут возникать существенные расхождения. Например, по итогам 2011 г. Росстатом было заявлено, что 36,5\% водки и ликероводочных изделий было произведено незаконно, а доля незаконного оборота водки, по расчетам Росалкогольрегулирования, составляла лишь $23 \%$ розничных продаж. В любом случае, объем неучтенного алкоголя оказался весьма значительным.

Еще один способ применения балансового метода связан с расчетами разницы между объемами розничных продаж импортного алкоголя, который не производится внутри страны, и объемами его зарегистрированного импорта. Данные Росстата и ФТС России свидетельствуют, что уровень продаж виски 
в 2010-2012 гг. в среднем превышал уровень импорта на 18-23\%. Если эти расчеты справедливы, то 16-19\% реализации виски осуществлялось незаконно, т.е. речь шла либо о контрабанде, либо о контрафактной (поддельной) продукции.

Еще больше усложняет картину тот факт, что балансовые расчеты не включают продажи неучтенного алкоголя, осуществляемые через торговые объекты и учреждения общепита, не имеющие соответствующих лицензий. Некоторые свидетельства по поводу такого рода нелегальных продаж были предъявлены агентством «Инфолайн», которое в 2014 г. провело исследование торговых объектов в 10 городах России. При сравнении реестров всех торговых объектов, торгующих алкоголем, с реестрами торговых объектов, получивших лицензии на торговлю алкогольными напитками, было выявлено, что 16\% из 24 тыс. торговых объектов продавали алкоголь без специальных лицензий ${ }^{6}$

Поскольку прямые статистические данные по неучтенному обороту алкогольной продукции в сколь-либо систематическом виде отсутствуют, мы привлекли косвенные эмпирические свидетельства о динамике количества алкоголя, изъятого по итогам проверок правоохранительными органами в силу того, что производство и оборот этого алкоголя проводились незаконно. Согласно этим данным, в конце 1990-х гг. уровень изымаемого незаконного алкоголя находился на максимально высоком уровне. В течение выделенного нами третьего этапа развития этот уровень резко упал и в середине 2000 -х гг. стабилизировался на относительно низкой отметке. Четвертый этап начался с дальнейшего уменьшения этого показателя в кризисный 2008 г., а в 2011-2014 гг. он устремился вверх. Конечно, объемы изымаемого незаконного алкоголя по отношению к общему объему продаж невелики, и по ним нельзя судить об абсолютных масштабах незаконного оборота алкогольной продукции, однако динамика данного показателя дает еще одно косвенное свидетельство происходящих изменений.

Добавим, что водка составляет от $1 / 3$ до $2 / 3$ изъятого незаконного алкоголя, a размеры изымаемого этилового спирта (основного ингредиента для изготовления водки) близки к размерам изъятой водки в течение почти всего изучаемого периода (рисунок 4). Это свидетельство подтверждает, что водка доминирует в составе производимого алкоголя сомнительного происхождения, проходящего через каналы незаконного оборота.

Интересно, что рост нелегального алкоголя сопровождается продолжающимся с середины 2000-х гг. снижением смертности от отравления алкоголем [Немщов 2016]. Дело в том, что значительная часть этого алкоголя не отличается от легального по своим свойствам и не представляет повышенной угрозы для здоровья и жизни людей, но угрожает государственному бюджету, недобирающему акцизные сборы.

Можно заключить, что в рамках четвертого этапа в 2010-е гг. произошла заметная экспансия рынка неучтенного алкоголя промышленного производства. Этот взлет может быть объяснен несколькими комплементарными обстоятельствами. Во-первых, с созданием Росалкогольрегулирования усилился контроль над рынками нерегистрируемого алкоголя, и растущая статистика изъятой нелегальной алкогольной продукции отчасти может быть результатом более активных действий контролирующих и правоохранительных органов, хотя мы ни в коей мере не можем считать это исчерпывающим объяснением. Во-вторых, в 2011-2014 гг.

6 Данные были представлены агентством «Инфолайн» на деловом форуме в Москве в мае 2014 г. 
вследствие проведения новой алкогольной политики произошло ускоренное повышение ставок акцизов и минимальных розничных цен на алкогольную продукцию, что явилось причиной соответствующего роста розничных цен на легальный алкоголь, и дополнительное распространение нелегального алкоголя могло стать побочным продуктом введенных фискальных мер. В-третьих, сыграло свою роль создание в 2010 г. Единого таможенного союза России, Беларуси и Казахстана, а в 2014 г. Евразийского экономического союза с присоединением Армении и Кыргызстана. В результате, по свидетельствам экспертов и участников рынка, через открытые внутренние границы хлынул поток дешевого и нерегистрируемого алкоголя в Россию, прежде всего из Казахстана [Радаев, Барсукова, Котельникова, Куракин 2010]. Помимо более низких издержек производства в Казахстане, существенную роль сыграло отсутствие гармонизации ставок акцизов на алкогольную продукцию между странами-членами ЕАЭС. Так, при пересчете в евро в 2016 г. ставки акцизов на крепкий алкоголь в Казахстане оказались почти в два раза ниже, чем в России, а разница ставок акциза на пиво и вино достигла четырех раз. Помимо того, что значительная часть ввозимой в Россию алкогольной продукции остается нерегистрируемой, она также и нелегальна, поскольку, продавая алкогольную продукцию на территории России, дилеры уклоняются от уплаты более высоких акцизных платежей. И наконец, в-четвертых, внесла свою лепту и начавшаяся в 2012 г., переросшая два года спустя в экономический кризис рецессия, которая побудила конечных покупателей к поиску более дешевых товаров и увеличила их склонности к приобретению продукции (в том числе алкогольной) сомнительного происхождения.

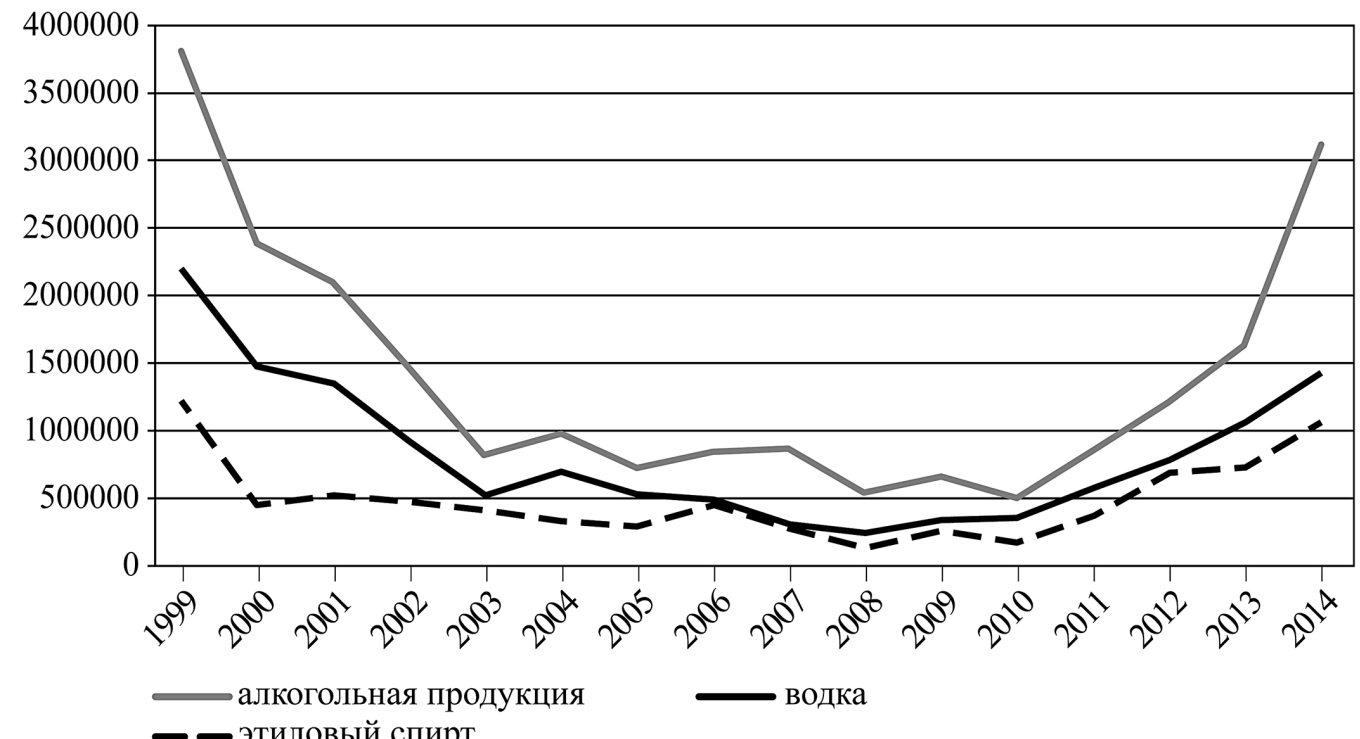

Рисунок 4. Объем алкогольной продукции, водки и этилового спирта, изъятых по результатам проверок в России в 1999-2014 гг., декалитры

Источник: данные Росстата, данные Росалкогольрегулирования 


\section{Легальность и легитимность}

Эволюция рынков нерегистрируемого алкоголя через четыре описанных нами этапа сопровождалась периодическими квалифицирующими действиями, переводящими определенные продукты, организации и транзакции из одной категории в другую. Это привело к постоянному движению двух границ - между легальным/ нелегальным и между легитимным/нелегитимным.

\section{Границы между легальным и нелегальным}

Изменение границ между легальным и нелегальным легко проиллюстрировать на примере юридического статуса домашнего алкоголя. Заметим, что производство, продажа и покупка самогона оставались вне закона и даже были предметом уголовной ответственности на протяжении большей части советского периода. В конце советской эпохи, в 1987 г., уголовная ответственность за изготовление самогона была заменена административной ответственностью, которая была ликвидирована в 2001 г., когда власти разрешили производство самогона (и других домашних алкогольных напитков) для собственных нужд, в то время как продажа самогона третьим лицам осталась нелегальным деянием. Примечательно то, что упомянутое освобождение от административной ответственности не привело к росту потребления самогона, как можно было ожидать. Это дает дополнительные основания утверждать, что изменение в законодательстве само по себе не является доминирующим фактором.

Законодательные нормы в отношении контрафактной продукции также претерпевали изменения: так, в 2002 г. произошла спецификация нормы о незаконном использовании зарегистрированных товарных знаков. Теперь к нему относились не только незаконное размещение чужого товарного знака на продукте, но и коммерческое использование продукта с ранее нанесенным чужим товарным знаком. Это означает, что незаконным стало не только изготовление, но и распространение контрафакта, изготовленного другими.

Классификации легальных и нелегальных форм продажи алкогольных напитков прошли через множественные изменения, когда вводились новые законодательные ограничения, касающиеся характера и расположения торговых объектов, где разрешалось торговать алкоголем: например, с 2006 г. продажа алкогольных напитков была запрещена в детских, образовательных, спортивных и культурных учреждениях и в общественном транспорте. Также вводились и новые ограничения относительно размера торговых точек: с 2012 г. такие торговые объекты должны были иметь не менее $50 \mathrm{~m}^{2}$ торговой площади в городских зонах и не менее $25 \mathrm{~m}^{2}$ в сельской местности. При этом объекты, торгующие алкоголем, должны были находиться на определенном расстоянии от образовательных, медицинских, спортивных и культурных заведений. С 2006 г. было запрещено торговать алкогольными напитками крепостью $15 \%$ этилового спирта и выше в нестационарных торговых объектах (киосках), индивидуально, из автомобилей, а в 2014 г. запрет на продажу в киосках распространился на весь алкоголь, включая пиво (которое к тому времени переквалифицировали в алкогольный напиток). 
Подвергались переопределению и транзакции путем изменения ограничений, касающихся времени продаж: так, с 2012 г. на федеральном уровне была запрещена продажа алкогольных напитков крепостью 5 градусов и выше в ночное время с 23 до 8 часов ${ }^{7}$. Произошла и переквалификация продуктов: в 2012 г. все напитки, содержащие более $0,5 \%$ этилового спирта, включая пиво и слабоалкогольные коктейли, были переведены в разряд алкогольных напитков и превратились в объект контроля со стороны госрегуляторов. В 2013 г. вино из отечественного винограда было квалифицировано как сельскохозяйственный продукт.

\section{Границьы между легитимным и нелегитимным}

Нелегальный характер деятельности с отсылками к букве закона необязательно сопряжен с нелегитимностью этой деятельности с точки зрения социальных восприятий [Van Schendel, Abraham 2005]. Переход из состояния легальности в состояние нелегальности и обратно может произойти в один момент - достаточно внести соответствующие изменения в действующее законодательство, но легитимность обретается или утрачивается намного медленнее вследствие подвижек в культурных ценностях. Мы выделяем две важные и взаимосвязанные, но все же относительно автономные причины сохранения (или несохранения) легитимности нелегальной деятельности. Первая причина вызвана неосведомленностью (недостатком конкретных знаний и общего понимания), вторая связана с толерантностью (терпимостью, готовностью принять). При неосведомленности действия воспринимаются как естественные и не связанные с какими-либо нарушениями; в случае же толерантности нарушения осознаются, но считаются оправданными.

Приведем несколько иллюстрирующих примеров. Первый пример: люди могут демонстрировать устойчивую толерантность по отношению к изготовлению и продаже домашнего алкоголя, даже если эта деятельность запрещена законом, воспринимая ее как проявление тактик выживания малообеспеченных слоев населения и одновременно как устойчивую культурную традицию. Второй пример: потребители могут приобретать контрафактный товар в силу неосведомленности и дефицита компетенций для различения оригинального продукта и качественной подделки. При этом потребители способны толерантно (или в данном случае лучше сказать - безразлично) относиться к несоблюдению прав интеллектуальной собственности, не считая их нарушение жизненно важной проблемой. Однако применительно к контрафактному алкоголю уровень толерантности должен быть более низок (по сравнению, например, с контрафактной одеждой или аксессуарами), потому что наряду с прочими продуктами питания такой алкоголь способен представлять немалую угрозу для здоровья человека, а порою и для его жизни. Третий пример: конечные потребители вряд ли в состоянии отличить легальный алкоголь промышленного производства от нелегального, если они оба произведены на одном и том же предприятии и совершенно идентичны по вкусу и качеству. И даже если они об этом узнают, то могут вполне толерантно относиться к обману

\footnotetext{
7 Многие региональные и местные власти ввели дополнительные ограничения времени продаж по сравнению с федеральной нормой.
} 
государства предприятиями, уклоняющимися от уплаты налогов, поскольку обман государства в России в принципе не воспринимается как страшное преступление. В то же время потребители, готовые приобрести неучтенный алкоголь промышленного производства, ожидают, что он будет продаваться по более низкой цене. Но если нелегальный алкоголь, произведенный со значительно более низкими издержками, продается по той же цене, что и алкоголь, законно выпущенный в оборот, то люди могут воспринимать это как обман и как нелегитимное действие. Все приведенные выше суждения, суммированные в таблице 1 , следует рассматривать как содержательные гипотезы для будущих исследований.

\section{Таблица 1. Причины сохранения легитимности нелегальных форм деятельности}

\begin{tabular}{|c|c|c|c|}
\hline \multirow{2}{*}{ Нелегальные виды деятельности } & \multirow{2}{*}{$\begin{array}{c}\text { Воспринимаются } \\
\text { как } \\
\text { нелегитимные }\end{array}$} & \multicolumn{2}{|c|}{ Воспринимаются как легитимные } \\
\hline & & $\begin{array}{c}\text { в силу } \\
\text { неосведомленности }\end{array}$ & $\begin{array}{c}\text { в силу } \\
\text { толерантности }\end{array}$ \\
\hline Продажа домашнего алкоголя & & & $(+)$ \\
\hline Фальсификация алкогольных напитков & $(+)$ & & \\
\hline $\begin{array}{l}\text { Нарушение прав интеллектуальной } \\
\text { собственности (незаконное использова- } \\
\text { ние товарного знака) }\end{array}$ & & $(+)$ & $(+)$ \\
\hline $\begin{array}{l}\text { Неучтенное производство с поддельными } \\
\text { акцизными марками и нелицензированная } \\
\text { торговля алкоголем }\end{array}$ & & $(+)$ & \\
\hline $\begin{array}{l}\text { Продажа нелегального алкоголя по цене } \\
\text { легального (обман потребителя) }\end{array}$ & $(+)$ & & \\
\hline $\begin{array}{l}\text { Продажа нелегального алкоголя по более } \\
\text { низким ценам вследствие экономии на } \\
\text { уплате налогов (обман государства) }\end{array}$ & & & $(+)$ \\
\hline
\end{tabular}

Границы между легитимным и нелегитимным зачастую размыты и различаются в зависимости от категории продукта. Уровень легитимности также способен меняться со временем, хотя эти изменения проявляют себя относительно медленно. К примеру, изготовление и распространение контрафактной продукции, процветавшее в 1990-е гг., было запрещено законом, но воспринималось как допустимое многими конечными потребителями и как неизбежное зло компаниями-правообладателями, в то же время нарушение закона в данном случае во многом игнорировалось государственными органами, отвечающими за правоприменение в силу ограниченных возможностей идентифицировать поддельный продукт и пресечь соответствующие практики [Kotelnikova 2011; Храмова 2012]. Тем не менее в 2000 -е гг. деятельность по изготовлению и распространению подделок и имитаций во многом утратила былую легитимность. Как мы описывали 
в предыдущих разделах данной работы, в 2002 и 2008 гг. было принято более развитое законодательство, защищающее торговые марки и их обладателей: импортируемый контрафактный алкоголь начали останавливать и конфисковывать на таможне; арбитражные суды все чаще выносили свои вердикты в пользу собственников торговых марок; да и сами компании-правообладатели стали активнее защищать свои права и бороться с подделками и имитациями в сотрудничестве с регулирующими и правоохранительными органами [Радаев, Барсукова, Котельникова 2008; Радаев, Барсукова, Котельникова, Куракин 2010]. Но, несмотря на очевидные позитивные тренды, общественное мнение в отношении контрафактной продукции оставалось амбивалентным. С одной стороны, конечные потребители демонстрировали низкий уровень терпимости к фальсификации продуктов питания (включая алкоголь), создающих явную угрозу для здоровья, а с другой стороны, они воспринимали нарушения прав интеллектуальной собственности как относительно безобидное действие при условии, что поддельные продукты продавались по значительно более низким ценам. Более того, если одни потребители действительно обманывались, покупая контрафактный товар, то другие приобретали его вполне осознанно [Grossman, Shapiro 1988].

\section{Основные выводы}

Рынки нерегистрируемого алкоголя гетерогенны, они имеют сложную структуру, и их нелегальность проистекает из разных оснований, включая нарушение прямых законодательных запретов, несоблюдение прав интеллектуальной собственности или уклонение от уплаты налогов. Легальная и нелегальная деятельность зачастую плотно переплетены: контрафактные товары могут продаваться легально зарегистрированными фирмами и учитываться в статистической и налоговой отчетности (разумеется, как оригинальный товар); массовые потребительские продукты с оригинальными товарными знаками могут нелегально производиться легальными предприятиями, которые просто не заявляют часть выпущенной продукции в целях уклонения от уплаты налогов; совершенно легально изготовленные товары могут продаваться ритейлерами с нарушением закона через торговые объекты, не имеющие надлежащих лицензий.

Анализ эмпирических данных подталкивает нас к следующим общим выводам. Во-первых, рынки нерегистрируемого алкоголя имеют тенденцию к расширению в периоды экзогенных политических и экономических шоков, таких как антиалкогольная кампания 1985-1987 гг., либеральная экономическая реформа 1992-1994 гг, финансовый кризис 1998 г. или рецессия, начавшаяся в 2012 г. В периоды же относительной экономической стабильности и роста рынки нерегистрируемого алкоголя сокращаются или, по крайней мере, остаются на прежнем уровне. Во-вторых, в некоторые периоды рынки регистрируемого и нерегистрируемого алкоголя движутся в противоположных направлениях (1980-1992, 1996-1997 и 2001-2007 гг.), в то время как в другие, более короткие периоды, они движутся параллельно (1993-1995 и 1998-2000 гг.). Таким образом, единая закономерность, позволяющая квалифицировать эти рынки как подобие сообщающихся сосудов, отсутствует. В-третьих, на разных этапах внешние политические и экономические 
шоки стимулируют развитие разных рынков нерегистрируемого алкоголя. Чтобы проследить закономерности в динамике этих рынков и воздействии основных факторов, мы построили таблицу 2.

Таблица 2. Основные стадии и факторы эволюции рынков нерегистрируемого алкоголя

\begin{tabular}{|c|c|c|c|c|}
\hline & \multicolumn{4}{|c|}{ Основные этапы } \\
\hline & $\begin{array}{c}\text { Поздний } \\
\text { социализм, } \\
\text { антиалкогольная } \\
\text { кампания } \\
\text { (1980-1991 гг.) }\end{array}$ & $\begin{array}{c}\text { Либеральная } \\
\text { реформа, } \\
\text { экономический } \\
\text { спад } \\
\text { (1992-1999 гг.) }\end{array}$ & $\begin{array}{c}\text { Консолидация } \\
\text { государства, } \\
\text { экономический } \\
\text { рост } \\
\text { (2000-2007 гг.) }\end{array}$ & $\begin{array}{c}\text { Экономическая } \\
\text { рецесия, новая } \\
\text { алкогольная } \\
\text { политика } \\
\text { (2008-2018 гг.) }\end{array}$ \\
\hline \multicolumn{5}{|c|}{ Рынки нерегистрируемого алкоголя } \\
\hline Домашний алкоголь & & & & $>$ \\
\hline Контрафактный алкоголь & - & & & - \\
\hline $\begin{array}{l}\text { Неучтенный алкоголь } \\
\text { промышленного производства }\end{array}$ & & & & \\
\hline \multicolumn{5}{|c|}{ Факторы } \\
\hline $\begin{array}{l}\text { Реальные располагаемые } \\
\text { доходы населения }\end{array}$ & & & & \\
\hline $\begin{array}{l}\text { Доступность легального } \\
\text { алкоголя }\end{array}$ & & & & \\
\hline $\begin{array}{l}\text { Санкции против нелегальных } \\
\text { дилеров }\end{array}$ & & & & \\
\hline $\begin{array}{l}\text { Эффективность деятельности } \\
\text { правоохранительных органов }\end{array}$ & & & & \\
\hline $\begin{array}{l}\text { Легализация участников } \\
\text { рынка }\end{array}$ & & & & \\
\hline $\begin{array}{l}\text { Толерантность } \\
\text { к нелегальным продуктам }\end{array}$ & & & & \\
\hline
\end{tabular}

Из таблищь 2 видно, что комбинация рынков нерегистрируемого алкоголя в России претерпела множество изменений, проходя через четыре этапа, каждый из которых был сопряжен со специфической констелляцией политических, правовых и экономических факторов. На каждом этапе одни нелегальные рынки выходили на передний план, в то время как другие демонстрировали нисходящие тренды.

На первом этапе позднего социализма и горбачевской антиалкогольной кампании (1980-1991 гг.) среди прочих нелегальных рынков доминировало производство домашнего алкоголя (самогона), особенно когда снижалась доступность 
легального алкоголя. Ужесточение санкций против самогоноварения не имело действенных последствий в силу низкой эффективности практик правоприменения и толерантности населения. Рынки контрафактной алкогольной продукции и неучтенной продукции промышленного производства оставались слаборазвитыми, в том числе благодаря пристальному контролю государства над деятельностью хозяйственных организаций.

На втором этапе, в ходе либеральной экономической реформы и экономического спада (1992-1999 гг.), самогон в значительной мере замещался легальным алкоголем. Российский рынок заполнился дешевым и низкокачественным отечественным и импортным алкоголем, включая нелегально произведенные, контрабандные и фальсифицированные алкогольные напитки. В условиях хронической слабости государства участники рынка в массовом порядке применяли так называемые серые схемы с целью ухода от налогообложения, а снижающиеся реальные доходы населения объясняли повышенную терпимость конечных покупателей к более дешевым нелегальным продуктам.

Это продолжалось до тех пор, пока в середине 1990-х гг. государство не усилило контроль над алкогольными рынками, приведший к росту легального и снижению нелегального алкоголя. После нового кризиса 1998 г. наблюдалась короткая повышательная волна нелегального алкоголя, затем начавшийся в 2000-е гг. экономический рост привел к дальнейшему повышению потребления легального алкоголя, а доля нелегального алкоголя вновь начала снижаться.

$\mathrm{C}$ наступлением третьего этапа консолидации государства и экономического роста (2000-2007 гг.) реальные располагаемые доходы населения начали устойчиво и быстро расти, и легальный алкоголь стал все более доступным в экономическом отношении. Росла и информированность покупателей, постепенно снижалась их толерантность по отношению к продуктам нелегальной деятельности. В то же время серьезно повысилась ответственность за несоблюдение закона, а правоприменение стало более эффективным. Все это привело к ступенчатой легализации бизнеса и сокращению зон действия нелегальных рынков.

Наконец, в ходе четвертого этапа экономической рецессии и кризиса (2008- 2018 гг.) темпы роста реальных доходов населения резко снизились, а затем и вовсе ушли в минус. Параллельно, с 2009 г., развернулась активная фаза довольно масштабной антиалкогольной реформы с введением широкого набора ограничительных мер в отношении производства и продаж алкогольной продукции. В этот период многие тенденции, образовавшиеся в течение третьей стадии экономического роста, прервались. Легальный алкоголь подорожал и стал менее доступным, что в особенности касалось импортного алкоголя с момента девальвации рубля в конце 2014 г. Конечные покупатели начали искать более экономичные варианты и сокращать потребление алкоголя. И, несмотря на попытки ужесточения государственного контроля над производством и распространением алкоголя, наблюдалась экспансия рынка неучтенного алкоголя промышленного производства, в то время как рынки домашнего и контрафактного алкоголя отошли на второй или даже третий план, стабилизируясь на исторически низких отметках.

Наряду с эволюцией рынков нерегистрируемого алкоголя, изменился характер вовлеченных участников рынка с точки зрения их статуса и роли в российской экономике. Домашний алкоголь (преимущественно самогон) изготовлялся и потреблялся в рамках домохозяйств, связанных прежде всего с низшими социальными 
слоями. Более поздний широкий приток контрафактного (поддельного) алкоголя был обеспечен массой относительно некрупных фирм, оперирующих в качестве «серых» дилеров в расширяющейся теневой экономике. С распространением неучтенного производства и продаж оригинального алкоголя промышленного производства в авангард вышли крупные легальные предприятия и лицензированные торговые компании. Будучи неотъемлемой частью легальной экономики, они совмещали легальные и нелегальные транзакции с целью ухода от лишнего (по их мнению) налогового бремени.

Указанные изменения в структуре рынков нерегистрируемого алкоголя подпитывались периодическими переквалификациями продуктов, организаций и транзакций с оспариванием и перемещением границ между легальным и нелегальным. Нелегальный статус мог быть приобретен или утрачен очень быстро вследствие изменений в действующем законодательстве, в то время как границы между легитимным и нелегитимным, как правило, оставались более размытыми и менялись намного медленнее. Некоторые нелегальные виды деятельности сохранили в той или иной степени свою легитимность благодаря неосведомленности или толерантности конечных потребителей и представителей госорганов, призванных осуществлять правоприменение.

Мы можем также заключить, что размер рынков нерегистрируемого алкоголя не слишком чувствителен к уровню правовых санкций, но в значительно большей мере зависит от эффективности практик правоприменения. Размер таких рынков отрицательно связан с уровнем готовности ведущих участников рынка соблюдать закон и защищать свои собственнические права, но положительно связан с уровнем неосведомленности о нелегальной деятельности и уровнем толерантности по отношению к ней.

В заключение хотелось бы отметить, что меры ограничительной антиалкогольной политики, как правило, приводят к снижению продаж легального алкоголя, в то время как рынки нерегистрируемого алкоголя способны жить своей жизнью и демонстрировать относительно независимую динамику, изучение которой требует дополнительных исследований и многомерной оптики. Нелегальные рынки, как кривые зеркала, способны давать меняющиеся и искаженные отражения легальных рынков, на одних стадиях они движутся параллельно легальным, на других могут следовать в противоположных направлениях.

\section{Литература}

Барсукова С.Ю. (2004) Неформальная экономика: экономико-социологический анализ. М.: ВШЭ.

Денисова И. (2010) Потребление алкоголя в России: влияние на здоровье и смертность // Центр экономических и финансовых исследований и разработок при Российской экономической школе. № 31 // www.cefir.ru/download.php?id=2437/

Заиграев Г.Г. (2002) Особенности российской модели потребления некоммерческого алкоголя // Социологические исследования. № 12. С. 33-41.

Немцов А.В. (2009) Алкогольная история России: новейший период. М.: Либроком.

Немцов А.В. (2016) Антиалкогольная кампания 2000 года: до, во время и после // Альманах Центра исследований экономической культуры. СПб.: Институт Гайдара. С. 45-70. 
Радаев В.В. (2007) Современные экономико-социологические концепции рынка // Радаев В.В., Добрякова М.С. (ред.) Анализ рынков в современной экономической социологии. М.: ВШЭ. С. 21-60.

Радаев В.В., Барсукова С.Ю., Котельникова 3.В. (2008) Рынки контрафактной продукции в России // Аналитика ЛЭСИ. Вып. 2. М.: ВШЭ // https://www.hse.ru/data/2010/01/02/12 $30732125 / \% \mathrm{D} 0 \% 9 \mathrm{~B} \% \mathrm{D} 0 \% \mathrm{AD} \% \mathrm{D} 0 \% \mathrm{~A} 1 \% \mathrm{D} 0 \% 98-2 . \mathrm{pdf}$

Радаев В.В., Барсукова С.Ю., Котельникова 3.В., Куракин А.А. (2010) Основные тенденции на рынках контрафактной продукции и возможное влияние Единого Таможенного Союза // Аналитика ЛЭСИ. Вып. 7. М.: ВШЭ // https://www.hse.ru/data/2011/02/09/120 $8663507 / \% \mathrm{D} 0 \% 9 \mathrm{~B} \% \mathrm{D} 0 \% \mathrm{AD} \% \mathrm{D} 0 \% \mathrm{~A} 1 \% \mathrm{D} 0 \% 98-7 . \mathrm{pdf}$

Радаев В.В., Котельникова 3.В. (2016) Изменение структуры потребления алкоголя в контексте государственной алкогольной политики в России // Экономическая политика. № 5. С. 92-117.

Радаев В.В., Бердышева Е.С., Конрой Н.В., Котельникова 3.В. (2017) Основные формы незаконного оборота продукции на потребительских рынках России и меры противодействия // Аналитика ЛЭСИ. Вып. 17. М.: ВШЭ.

Храмова Е.Ф. (2012) Амбивалентность отношения потребителей к контрафактной продукции // Экономическая социология. № 4 (13). С. 116-154.

Andrienko Y., Nemtsov A. (2005) Estimation of Individual Demand for Alcohol // Economics Education and Research Consortium Working Paper Series, no 05/10.

Beckert J., Wehinger F. (2011) In the Shadow. Illegal Markets and Economic Sociology // MPIfG Discussion Paper, no 11/9. Cologne: Max Planck Institute for the Study of Societies // http://www.mpifg.de/pu/mpifg_dp/dp11-9.pdf

Bhattacharya J., Gathmann C., Miller G. (2012) The Gorbachev Anti-Alcohol Campaign and Russia's Mortality Crisis // IZA Discussion Paper, no 6783 // https://www.econstor.eu/bitstream/10419/62393/1/722416504.pdf

Byrnes J., Shakeshaft A., Petrie D., Doran C. (2013) Can Harms Associated with High-Intensity Drinking Be Reduced by Increasing the Price of Alcohol? // Drug and Alcohol Review, vol. 32, pp. 27-30.

de Goeij M.C.M., Suhrcke M., Toffolutti V., van de Mheen D., Schoenmakers N.V., Kunst A.E. (2015) How Economic Shocks Affect Alcohol Consumption and Alcohol-Related Health Problems: A Realist Systematic Review // Social Science and Medicine, vol. 131, pp. 131-146.

Feige E.L. (1990) Defining and Estimating Underground and Informal Economies: The New Institutional Economics Approach // World Development, vol. 18, no 7, pp. 989-1002.

Fligstein N., Dauter L. (2007) The Sociology of Markets // Annual Review of Sociology, vol. 33, pp. $105-128$.

Fourcade M. (2007) Theories of Markets, Theories of Society // American Behavioral Scientist, vol. 50, no 8, pp. 1015-1034.

Gil A., Polikina O., Koroleva N., McKee M., Tomkins S., Leon D.A. (2009) Availability and Characteristics of Nonbeverage Alcohols Sold in 17 Russian Cities in 2007 // Alcoholism: Clinical and Experimental Research, vol. 33, pp. 79-85.

Grossman G.M., Shapiro C. (1988) Foreign Counterfeiting of Status Goods // The Quarterly Journal of Economics, vol. 103, no 1, pp. 79-100.

Haworth A., Simpson R. (2004) Moonshine Markets: Issues in Unrecorded Alcohol Beverage Production and Consumption, New York and Hover: Brunner-Routledge.

Jukkala T., Makinen I.H., Ferlander S., Vagero D., Kaslitsyna O. (2008) Economic Strain, Social Relations, Gender, and Binge Drinking in Moscow // Social Science and Medicine, vol. 66, pp. 663-674. DOI 10.1016/j.socscimed.2007.10.017

Kotelnikova Z. (2011) Goods with Fake Faces: Why Owners of Trademarks Contribute to Counterfeiting // Economy in Changing Society: Consumption, Markets, Organizations and Social Policies (ed. Nawojczyk M.), Cambridge: Cambridge Publishing, pp. 91-113.

Kotelnikova Z. (2017) Explaining Counterfeit Alcohol Purchases in Russia // Alcoholism: Clinical and Experimental Research, vol. 41, no 4, pp. 810-819.

Lachenmeier D.W., Taylor B.J., Rehm J. (2011) Alcohol Under the Radar: Do We Have Policy Options Regarding Unrecorded Alcohol? // International Journal of Drug Policy, vol. 22, pp. $153-160$. 
Leon D.A., Shkolnikov V.M., McKee V. (2009) Alcohol and Russian Mortality: A Continuing Crisis // Addiction, vol. 104, no 10, pp. 1630-1636.

Lindström M. (2005) Social Capital, the Miniaturisation of Community and Consumption of Homemade Liquor and Smuggled Liquor During the Past Year: A Population-Based Study // European Journal of Public Health, vol. 15, no 6, pp. 593-600.

Moskalewicz J., Simpura J. (2000) The Supply of Alcoholic Beverages in Transitional Conditions: The Case of Central and Eastern Europe // Addiction, vol. 95, no 4, pp. 505-522.

Neufeld M., Rehm J. (2013) Alcohol Consumption and Mortality in Russia since 2000: Are there any Changes Following the Alcohol Policy Changes Starting in 2006? // Alcohol and Alcoholism, vol. 48, no 2, pp. 222-230.

Popova S., Rehm J., Patra J., Zatonski W. (2007) Comparing Alcohol Consumption in Central and Eastern Europe to Other European Countries // Alcohol and Alcoholism, vol. 42, no 5, pp. 465-473.

Portes A. (2010) Economic Sociology: A Systematic Inquiry, Princeton, Oxford: Princeton University Press.

Radaev V. (2005) Informal Institutional Arrangements and Tax Evasion in the Russian Economy // Networks, Trust and Social Capital: theoretical and Empirical Investigations from Europe (ed. Koniordos S.), Aldershot: Ashgate, pp. 189-203.

Radaev V. (2016) Divergent Drinking Patterns and Factors Affecting Homemade Alcohol Consumption (The Case of Russia) // International Journal of Drug Policy, vol. 34, pp. 88-95.

Radaev V. (2017) A Crooked Mirror. The Evolution of Illegal Alcohol Markets in Russia since the Late Socialist Period // The Architecture of Illegal Markets: Towards an Economic Sociology of Illegality in the Economy (eds. Beckert J., Dewey M.), Oxford: Oxford University Press, pp. 218-241.

Rehm J., Kailasapillai S., Larsen E., Rehm M.X., Samokhvalov A.V., Shield K.D., Roerecke M., Lachenmeier D.W. (2014) A Systematic Review of the Epidemiology of Unrecorded Alcohol Consumption and the Chemical Composition of Unrecorded Alcohol // Addiction, vol. 109 , no 6 , pp. 880-893.

Rehm J., Kanteres F., Lachenmeier D.W. (2010) Unrecorded Consumption, Quality of Alcohol and Health Consequences // Drug and Alcohol Review, vol. 29, pp. 426-436.

Rogers D. (2005) Moonshine, Money, and the Politics of Liquidity in Rural Russia // American Ethnologist, vol. 32, no 1, pp. 63-81.

Roshchina Y. (2013) To Drink or not to Drink: The Microeconomic Analysis of Alcohol Consumption in Russia in 2006-2010. Working Paper WP BRP 20/SOC/2013, Moscow: HSE.

Rutter J., Bryce J. (2008) The Consumption of Counterfeit Goods: 'Here be Pirates? // Sociology, vol. 42, no 6, pp. 1146-1164.

Skog O.J. (1986) The Long Waves of Alcohol Consumption: A Social Network Perspective on Cultural Change // Social Networks, vol. 8, pp. 1-32.

Thamarangsi T. (2013) Unrecorded Alcohol: Significant Neglected Challenges // Addiction, vol. 108, no 12, pp. 2048-2050.

Treisman D. (2008) Alcohol and Early Death in Russia: The Political Economy of Self-Destructive Drinking. Working paper WP3/2008/02, Moscow: HSE.

Treml V.G. (1982) Alcohol in the USSR. A Statistical Study, Durham, NC: Duke Press Policy Studies.

Treml V. (1997) Soviet and Russian Statistics on Alcohol Consumption. Premature Death in the New Independent States // Committee on Population, Commission on Behavioral and Social Sciences and Education, National Research Council (eds. Bobadilla J.L., Costello C.A., Mitchell F.), Washington, DC: National Academy Press, pp. 220-238.

Van Schendel W., Abraham I. (eds.) (2005) Illicit Flows and Criminal Things: States, Borders, and the Other Side of Globalization, Bloomington: Indiana University Press.

Wagenaar A.C., Salois M.J., Komro K.A. (2009) Effects of Beverage Alcohol Price and Tax Levels on Drinking: A Meta-Analysis of 1003 Estimates from 112 studies // Addiction, vol. 104, no 2, pp. 179-190.

WHO (2014) // Global Status Report On Alcohol and Health, Geneva: World Health Organization. 


\title{
The Kingdom of Crooked Mirrors: the Evolution of Illegal Alcohol Markets in Russia from the 1980s
}

\author{
V. RADAEV*
}

\begin{abstract}
*Vadim Radaev - DSc in Economics and Sociology, Professor, Head, Laboratory for Studies in Economic Sociology, National Research University Higher School of Economics. Address: 20, Myasnitskaya St., Moscow, 101000, Russian Federation. E-mail: radaev@hse.ru
\end{abstract}

Citation: Radaev V. (2018) The Kingdom of Crooked Mirrors: the Evolution of Illegal Alcohol Markets in Russia from the 1980s. Mir Rossii, vol. 27, no 3, pp. 28-60 (in Russian). DOI: $10.17323 / 1811-038 X-2018-27-3-28-60$

\begin{abstract}
This study examines the evolution of heterogeneous illegal markets in Russia from the 1980s with a particular emphasis on the markets of homemade, counterfeit and otherwise illegally manufactured alcohol. The markets' are illegal in different ways, including violations of the formal ban on the market exchange of certain products, non-compliance with intellectual property rights, and tax evasion. Multiple sources of statistical and survey data are used to demonstrate that the composition of illegal alcohol markets in Russia developed through four different stages, following political, legislative and economic changes. These stages are: 1) late socialism and the Gorbachev's antialcohol campaign (1980-1991); 2) liberal reforms and economic collapse (1992-1999); 3 ) state consolidation and economic growth (2000-2007); and 4) economic recession and new anti-alcohol reforms (2008-today). At each stage, some of these markets became dominant, whereas others were unchanged or trended downward. At the first stage of late socialism, homemade alcohol was dominant. At the second stage of liberal reforms, it was partially replaced by smuggled and counterfeit alcoholic beverages. At the third stage of state consolidation and economic growth, illegal alcohol markets shrank. Finally, at the fourth stage, positive trends were interrupted, and illegally manufactured alcohol became the dominant form of the illegal alcohol market. The obtained data show that illegal alcohol markets tend to grow in periods of exogenous political or economic stressors, whereas in periods of relative economic stability and growth, illegal alcohol markets shrink or remain at the same level. At some stages, illegal markets may move in parallel with legal markets, whereas at other stages, they may move in the opposite direction. Changes in the structure of illegal markets are backed by a continuous requalification of products, organizations and transactions contesting the boundaries between legality and illegality. Some illegal activities retain their legitimacy because of the ignorance or tolerance of enforcement agencies and final consumers. Boundaries between legitimate and illegitimate activities are blurred and move slowly.
\end{abstract}

Key words: economic sociology, consumer markets, illegal markets, alcohol consumption, legality and legitimacy, Russia 


\section{References}

Andrienko Y., Nemtsov A. (2005) Estimation of Individual Demand for Alcohol. Economics Education and Research Consortium Working Paper Series, no 05/10.

Barsukova S.Yu. (2004) Neformal'naya ekonomika: ekonomiko-sotsiologicheskij analiz [Informal Economy: Economic Sociology Approach], Moscow: HSE.

Beckert J., Wehinger F. (2011) In the Shadow. Illegal Markets and Economic Sociology. MPIfG Discussion Paper, no 11/9, Cologne: Max Planck Institute for the Study of Societies. Available at: http://www.mpifg.de/pu/mpifg_dp/dp11-9.pdf, accessed 31 May 2018.

Bhattacharya J., Gathmann C., Miller G. (2012) The Gorbachev Anti-Alcohol Campaign and Russia's Mortality Crisis. IZA Discussion Paper, no 6783. Available at: https://www.econstor.eu/bitstream/10419/62393/1/722416504.pdf, accessed 31 May 2018.

Byrnes J., Shakeshaft A., Petrie D., Doran C. (2013) Can Harms Associated with High-Intensity Drinking Be Reduced by Increasing the Price of Alcohol? Drug and Alcohol Review, vol. 32, pp. 27-30.

Denisova I. (2010) Potreblenie alkogolya v Rossii: vliyanie na zdorov'e i smertnost' [Consumption of Alcohol in Russia: Effect on Health and Mortality]. Tsentr ekonomicheskikh i finansovykh issledovanij i razrabotok pri Rossijskoj ekonomicheskoj shkole [Center for Economic and Financial Research and Development at the Russian School of Economics], no 31. Available at: www.cefir.ru/download.php?id=2437/, accessed 31 May 2018.

de Goeij M.C.M., Suhrcke M., Toffolutti V., van de Mheen D., Schoenmakers N.V., Kunst A.E. (2015) How Economic Shocks Affect Alcohol Consumption and Alcohol-Related Health Problems: A Realist Systematic Review. Social Science and Medicine, vol. 131, pp. 131-146.

Feige E.L. (1990) Defining and Estimating Underground and Informal Economies: The New Institutional Economics Approach. World Development, vol. 18, no 7, pp. 989-1002.

Fligstein N., Dauter L. (2007) The Sociology of Markets. Annual Review of Sociology, vol. 33, pp. $105-128$.

Fourcade M. (2007) Theories of Markets, Theories of Society. American Behavioral Scientist, vol. 50, no 8, pp. 1015-1034.

Gil A., Polikina O., Koroleva N., McKee M., Tomkins S., Leon D. A. (2009) Availability and Characteristics of Nonbeverage Alcohols Sold in 17 Russian Cities in 2007. Alcoholism: Clinical and Experimental Research, vol. 33, pp. 79-85.

Grossman G. M., Shapiro C. (1988) Foreign Counterfeiting of Status Goods. The Quarterly Journal of Economics, vol. 103, no 1, pp. 79-100.

Haworth A., Simpson R. (2004) Moonshine Markets: Issues in Unrecorded Alcohol Beverage Production and Consumption, New York and Hover: Brunner-Routledge.

Jukkala T., Makinen I.H., Ferlander S., Vagero D., Kaslitsyna O. (2008) Economic Strain, Social Relations, Gender, and Binge Drinking in Moscow. Social Science and Medicine, vol. 66, pp. 663-674. DOI 10.1016/j.socscimed.2007.10.017

Khramova E.F. (2012) Ambivalentnost' otnosheniya potrebitelej k kontrafaktnoj produktsii [Ambivalence of Consumer Attitudes to Counterfeiting]. Ekonomicheskaya sotsiologiya, vol. 13, no 4, pp. 116-154.

Kotelnikova Z. (2011) Goods with Fake Faces: Why Owners of Trademarks Contribute to Counterfeiting. Economy in Changing Society: Consumption, Markets, Organizations and Social Policies (ed. Nawojczyk M.), Cambridge: Cambridge Publishing, pp. 91-113.

Kotelnikova Z. (2017) Explaining Counterfeit Alcohol Purchases in Russia. Alcoholism: Clinical and Experimental Research, vol. 41, no 4, pp. 810-819.

Lachenmeier D.W., Taylor B.J., Rehm J. (2011) Alcohol Under the Radar: Do We Have Policy Options Regarding Unrecorded Alcohol? International Journal of Drug Policy, vol. 22, pp. 153-160.

Leon D.A., Shkolnikov V.M., McKee V. (2009) Alcohol and Russian Mortality: A Continuing Crisis. Addiction, vol. 104, no 10, pp. 1630-1636.

Lindström M. (2005) Social Capital, the Miniaturisation of Community and Consumption of Homemade Liquor and Smuggled Liquor During the Past Year: A Population-Based Study. European Journal of Public Health, vol. 15, no 6, pp. 593-600. 
Moskalewicz J., Simpura J. (2000) The Supply of Alcoholic Beverages in Transitional Conditions: The Case of Central and Eastern Europe. Addiction, vol. 95, no 4, pp. 505-522.

Nemtsov A.V. (2009) Alkogol'naya istoriya Rossii: novejshij period [Alcoholic History of Russia: The New Times], Moscow: Librocom.

Nemtsov A.V. (2016) Antialkogolnaya kampaniya 2000 goda: do, vo vremya i posle. Almanakh tsentra issledovanij ekonomicheskoj kultury [Almanac of the Center for the Study of Economic Culture], SPb: Gaidar Institute, pp. 45-70.

Neufeld M., Rehm J. (2013) Alcohol Consumption and Mortality in Russia since 2000: Are there any Changes Following the Alcohol Policy Changes Starting in 2006? Alcohol and Alcoholism, vol. 48, no 2, pp. 222-230.

Popova S., Rehm J., Patra J., Zatonski W. (2007) Comparing Alcohol Consumption in Central and Eastern Europe to Other European Countries. Alcohol and Alcoholism, vol. 42, no 5, pp. 465-473.

Portes A. (2010) Economic Sociology: A Systematic Inquiry, Princeton, Oxford: Princeton University Press.

Radaev V. (2005) Informal Institutional Arrangements and Tax Evasion in the Russian Economy. Networks, Trust and Social Capital: theoretical and Empirical Investigations from Europe (ed. Koniordos S.), Aldershot: Ashgate, pp. 189-203.

Radaev V.V. (2007) Sovremennye ekonomiko-sotsiologicheskie kontseptsii rynka [Contemporary Concepts of the Market in Economic Sociology]. Analiz rynkov $v$ sovremennoj ekonomicheskoj sotsiologii [Analysis of Markets in Modern Economic Sociology] (eds. Radaev V.V., Dobryakova M.S.), Moscow: HSE, pp. 21-60.

Radaev V. (2016) Divergent Drinking Patterns and Factors Affecting Homemade Alcohol Consumption (The Case of Russia). International Journal of Drug Policy, vol. 34, pp. 88-95.

Radaev V. (2017) A Crooked Mirror. The Evolution of Illegal Alcohol Markets in Russia since the Late Socialist Period. The Architecture of Illegal Markets: Towards an Economic Sociology of Illegality in the Economy (eds. Beckert J., Dewey M.), Oxford: Oxford University Press, pp. 218-241.

Radaev V.V., Barsukova S.Yu., Kotelnikova Z.V. (2008) Rynki kontrafaktnoy produktsii v Rossii [Markets for Counterfeit Goods in Russia]. Analytika Laboratorii ekonomikosotsiologicheskikh issledovanij [Analytics of the Laboratory of Economic and Sociological Research], vol. 2, Moscow: HSE. Available at: https://www.hse.ru/data/2010/01/02/123073 2125/\%D0\%9B\%D0\%AD\%D0\%A1\%D0\%98-2.pdf, accessed 31 May 2018.

Radaev V.V., Barsukova S.Yu., Kotelnikova Z.V., Kurakin A.A. (2010) Osnovnye tendentsii na rynkakh kontrafaktnoj produktsii i vozmozhnoe vliyanie Edinogo Tamozhennogo Soyuza [Major Trends in the Markets for Counterfeit Goods and the Impact of the New Custom Union]. Analytika Laboratorii ekonomiko-sotsiologicheskikh issledovanij [Analytics of the Laboratory of Economic and Sociological Research], vol. 7, Moscow: HSE. Available at: https://www.hse.ru/data/2011/02/09/1208663507/\%D0\%9B\%D0\%AD\%D0\%A1\%D0\% 98-7.pdf, accessed 31 May 2018.

Radaev V.V., Kotelnikova Z.V. (2016) Izmenenie struktury potrebleniya alkogolya v kontekste gosudarstvennoj alkogolnoj politiki v Rossii [Changes in the Structure of Alcohol Consumption in the Context of the State Alcohol Policy in Russia]. Ekonomicheskaya politika, no 5, pp. 92-117.

Radaev V.V., Berdysheva E.S., Konroy N.V., Kotelnikova Z.V. (2017) Osnovnye formy nezakonnogo oborota produktsii na potrebitel'skikh rynkakh Rossii i mery protivodejstviya [Illegal Turnover of Goods in the Russian Consumer Markets and Policy Measures]. Analytika Laboratorii ekonomiko-sotsiologicheskikh issledovanij [Analytics of the Laboratory of Economic and Sociological Research], vol. 17, Moscow: HSE.

Rehm J., Kailasapillai S., Larsen E., Rehm M.X., Samokhvalov A.V., Shield K.D., Roerecke M., Lachenmeier D.W. (2014) A Systematic Review of the Epidemiology of Unrecorded Alcohol Consumption and the Chemical Composition of Unrecorded Alcohol. Addiction, vol. 109 , no 6 , pp. $880-893$.

Rehm J., Kanteres F., Lachenmeier D. W. (2010) Unrecorded Consumption, Quality of Alcohol and Health Consequences. Drug and Alcohol Review, vol. 29, pp. 426-436. 
Rogers D. (2005) Moonshine, Money, and the Politics of Liquidity in Rural Russia. American Ethnologist, vol. 32, no 1, pp. 63-81.

Roshchina Y. (2013) To Drink or not to Drink: The Microeconomic Analysis of Alcohol Consumption in Russia in 2006-2010. Working Paper WP BRP 20/SOC/2013, Moscow: HSE.

Rutter J., Bryce J. (2008) The Consumption of Counterfeit Goods: 'Here be Pirates? Sociology, vol. 42, no 6, pp. 1146-1164.

Skog O.J. (1986) The Long Waves of Alcohol Consumption: A Social Network Perspective on Cultural Change. Social Networks, vol. 8, pp. 1-32.

Thamarangsi T. (2013) Unrecorded Alcohol: Significant Neglected Challenges. Addiction, vol. 108, no 12 , pp. 2048-2050.

Treisman D. (2008) Alcohol and Early Death in Russia: The Political Economy of Self-Destructive Drinking. Working paper WP3/2008/02, Moscow: HSE.

Treml V.G. (1982) Alcohol in the USSR. A Statistical Study, Durham, NC: Duke Press Policy Studies.

Treml V. (1997) Soviet and Russian Statistics on Alcohol Consumption. Premature Death in the New Independent States. Committee on Population, Commission on Behavioral and Social Sciences and Education, National Research Council (eds. Bobadilla J.L., Costello C.A., Mitchell F.), Washington, DC: National Academy Press, pp. 220-238.

Van Schendel W., Abraham I. (eds.) (2005) Illicit Flows and Criminal Things: States, Borders, and the Other Side of Globalization, Bloomington: Indiana University Press.

Wagenaar A.C., Salois M.J., Komro K.A. (2009) Effects of Beverage Alcohol Price and Tax Levels on Drinking: A Meta-Analysis of 1003 Estimates from 112 Studies. Addiction, vol. 104, no 2, pp. 179-190.

Zaigraev G.G. (2002) Osobennosti rossijskoj modeli potrebleniya nekommercheskogo alkogolya [Specific Features of the Russian Model of Noncommercial Alcohol Consumption], Sotsiologicheskie issledovaniya, no 12, pp. 33-41.

WHO (2014). Global Status Report On Alcohol and Health, Geneva: World Health Organization. 